\title{
Population and Reproductive Biology of the Channeled Whelk, Busycotypus canaliculatus, in the US Mid-Atlantic
}

\author{
Robert A. Fisher \\ Virginia Institute of Marine Science, rfisher@vims.edu \\ David Rudders \\ Virginia Institute of Marine Science, rudders@vims.edu
}

Follow this and additional works at: https://scholarworks.wm.edu/vimsarticles

Part of the Marine Biology Commons

\section{Recommended Citation}

Fisher, Robert A. and Rudders, David, "Population and Reproductive Biology of the Channeled Whelk, Busycotypus canaliculatus, in the US Mid-Atlantic" (2017). VIMS Articles. 304.

https://scholarworks.wm.edu/vimsarticles/304 


\title{
POPULATION AND REPRODUCTIVE BIOLOGY OF THE CHANNELED WHELK, BUSYCOTYPUS CANALICULATUS, IN THE US MID-ATLANTIC
}

\author{
ROBERT A. FISHER* AND DAVID B. RUDDERS \\ Virginia Institute of Marine Science, College of William and Mary, PO Box 1346, Gloucester Point, \\ VA 23062
}

\begin{abstract}
Channeled whelks, Busycotypus canaliculatus, support commercial fisheries throughout their range along the US Atlantic seaboard. Given the modest amounts of published information available on channeled whelk, this study focuses on understanding the temporal and spatial variations in growth and reproductive biology in the Mid-Atlantic region. Channeled whelks were sampled from three inshore commercially harvested resource areas in the US Mid-Atlantic: Ocean City, MD (OC); Eastern Shore of Virginia (ES); and Virginia Beach, VA (VB). The largest whelk measured 230-mm shell length (SL) and was recorded from OC. Mean SL was largest in OC site $(158.1 \mathrm{~mm})$, followed by ES $(137.6 \mathrm{~mm})$ and then VB $(132.4 \mathrm{~mm})$. Both VB and ES populations showed a unimodal length-frequency distribution with the single peak at SL less than minimum landing size (MLS) for those regions, whereas OC population showed a bimodal (two peaks) distribution with the smaller peak at SL less than the MLS for that region and larger peak at SL greater than the MLS. Brody growth rate coefficient $(k)$ was higher in males than females from all areas and highest for both sexes in VB (Male 0.245, Female 0.155), followed by ES (Male 0.220, Female 0.151) and then OC (Male 0.112, Female 0.100). The median size (SL) at 50\% mature varied between resource area and sex. Males from ES and VB reached maturity at a smaller mean size (123 and $121 \mathrm{~mm}$, respectively) than OC (134 mm). Females from VB reached maturity at a smaller size $(148.9 \mathrm{~mm})$ than ES $(157.6 \mathrm{~mm})$ and OC $(158.6 \mathrm{~mm})$. Recruitment to the fishery was estimated to occur at $\sim 6 \mathrm{y}$ for VB and $\sim 7-8 \mathrm{y}$ for ES and OC and was calculated from length at age estimates from von Bertalanffy growth model. Under current MLS for each area, whelk harvested from VB were recruited into the fishery at a much younger age compared with those from OC. The probability of females reaching MLS before sexual maturity in all three commercially targeted resource areas is quite low given current MLS.
\end{abstract}

KEY WORDS: whelk, Busycotypus canaliculatus, Melongenidae, Western Atlantic, age, growth, maturity

\section{INTRODUCTION}

Two species of large, predatory marine gastropods account for most whelk harvested in the US Mid-Atlantic. Channeled whelk Busycotypus canaliculatus (Linnaeus, 1758) and the closely related knobbed whelk Busycon carica (Gmelin, 1791), both members of the Melongenidae family are found along the Western Atlantic coast of North America from Cape Cod, MA to Cape Canaveral, FL (Abbott 1974, Edwards \& Harasewych 1988). In Virginia, the knobbed whelk is largely harvested in estuarine habitats whereas the channeled whelk is exploited in both near and offshore marine habitats, although some mixing of the two species is observed along the inshore shallow waters of the continental shelf. Channeled whelks are the focus of commercial fisheries throughout their range (Davis \& Sisson 1988, DiCosimo 1988, Bruce 2006, Eversole et al. 2008). In Virginia, most channeled whelks are harvested by baited traps (pots) along the Virginia coast within near-shore state (within 3 miles) and off-shore ( $>3$ miles) federal waters. Whelk meats are removed from shells for distribution to various markets.

In the 1980s, the channeled whelk fishery in Virginia began as an unregulated fishery with fishermen working in state waters. Biological assessment information for the more accessible knobbed whelk was used as a proxy to formulate generalized whelk fishery guidelines. In the early 1990s, experimental fishing permits were issued by Virginia's fisheries regulatory agency for pot fishing whelk (conch) with the objective to generate reproductive biology and fisheries stock information for more marketable channeled whelk in state and

*Corresponding author. E-mail: rfisher@vims.edu DOI: $10.2983 / 035.036 .0215$ federal waters. This effort provided poor and inconsistent data resulting in limited information gained specific to Busycotypus canaliculatus. Despite the data gap, the channeled whelk fishery expanded within Virginia and throughout the Mid-Atlantic during the 1990s as fishermen diversified their efforts. Efforts peaked in Virginia in the late 1990s, decreased in the early 2000s, and increased again in 2010 as shellstock (whole, live whelk) prices increased to levels three times higher than prices in the 1990s. In 2000, the Virginia conch pot fishery consisted of approximately 50 boats and 150 fishermen which supported processing, distribution, and bait industries generating a total estimated economic value to Virginia in excess of \$42 M (Manion et al. 2000).

Mid-Atlantic States with developing whelk fisheries enacted separate whelk management plans based on the data-poor Virginia whelk fishery, which used knobbed whelk biological assessment information. These same states imposed different minimum landing size (MLS, SL) requirements. Currently, the MLS for Mid-Atlantic States are $127 \mathrm{~mm}$ (5 in.) in New Jersey, $152.4 \mathrm{~mm}$ (6 in.) in Maryland and Delaware, and $139.7 \mathrm{~mm}$ (5.5 in.) in Virginia. With declining size of individual landed whelk observed within various resource areas in the Mid-Atlantic, coupled with increased fishermen complaints of undersize whelk being harvested and legally landed by fishermen from adjoining states, basic biological information of species governing the fishery was questioned. A central issue posed by the industry focused on understanding age/size at sexual maturity and the relevancy of multiple MLS within the Mid-Atlantic whelk fishery.

With modest amounts of published information available on Busycotypus caniculatus, research was initiated in 2009 across various resource areas in the Mid-Atlantic related to channeled whelk aging, reproduction, growth through maturity, age at 
maturity, and population structure. Work by Harding (2011) described larval to juvenile stage of growth of B.caniculatus, however, no information was available on age at sexual maturity and growth rates through recruitment to the fishery for this species. Peemoeller and Stevens (2012) have described age, size, and sexual maturity of B.canaliculatus in Buzzards Bay, MA, providing the first published biological assessment of this species.

Results from this study focus on the Busycotypus canaliculatus fishery in the Mid-Atlantic region, in the context to temporal and spatial variations in growth and reproductive biology as well as size at sexual maturity. Findings are discussed with respect to the suitability of current MLS regulations in place to manage this species across the Mid-Atlantic. This information will provide basic life history information to support the currently poor data assessment of whelk in the region.

\section{MATERIALS AND METHODS}

Samples of Busycotypus canaliculatus were collected from three different near-shore resource areas in the Mid-Atlantic region (Fig. 1); Maryland/Delaware border (OC), Eastern Shore of Virginia (ES), and Virginia Beach, VA (VB), during commercial fishing trips. Whelk were collected with traditional open-top, wood slat whelk (conch) traps $(58 \times 58 \times 28 \mathrm{~cm})$ baited with horseshoe crab sections placed in bait bags. Sampling sites were representative of near-shore whelk resource areas (OC, 14-16 m; ES, 8.5-10.5 m; VB, 9-10.5 m depth range) targeted by the commercial fishery, but these areas do not represent the full range of the Mid-Atlantic fishery. Commercial whelk trap have slats spaced $34 \mathrm{~mm}$ apart which prevented the retention of whelk approximately less than 82-mm SL (SL). As a result, juvenile whelks were not largely represented in the collected samples. Bottom temperatures were estimated by inserting a probe thermometer directly into the foot of the whelk immediately upon landing on the vessel. Initial whelk collections from all three sites were conducted during November 2009. Observed bottom water temperatures during the initial sampling were $12.5^{\circ} \mathrm{C}(\mathrm{OC}), 15^{\circ} \mathrm{C}(\mathrm{ES})$, and $16.2^{\circ} \mathrm{C}(\mathrm{VB})$.

To better understand the population structure and reproductive potential of Busycotypus canaliculatus within the three resource areas, additional limited, seasonal sampling was performed from May 2010 through January 2011. Collected whelks were transported to the Virginia Institute of Marine Science (VIMS) for processing. A subsample of 20-57 fresh, live whelk representing available size classes from each sample (September 2010 VB sample only three whelks were collected) were processed for reproductive histological analysis with the remaining whelk frozen whole at $-20^{\circ} \mathrm{C}$ for future analysis. All whole whelks were weighed for total weight, measured for SL (SL; spire apex to the edge of siphonal canal), and shell width [SW; maximum straightline distance measured across the shell perpendicular to shells length (coiling) axis] to nearest $1 \mathrm{~mm}$ (Fig. 1). Only whelks with intact, unbroken siphonal canals were measured. In addition to the commercially collected whelk samples, two live small (58.2 and $62.9 \mathrm{~mm} \mathrm{SL}$ ) B. canaliculatus whelk were collected from the beach in $\mathrm{OC}$ and used to provide length-at-age data for the younger aged animals that are lacking from the commercially collected samples because of trap size-selectivity.

Fresh samples evaluated histologically were processed by first removing bodies from the shell. A hole was notched in the

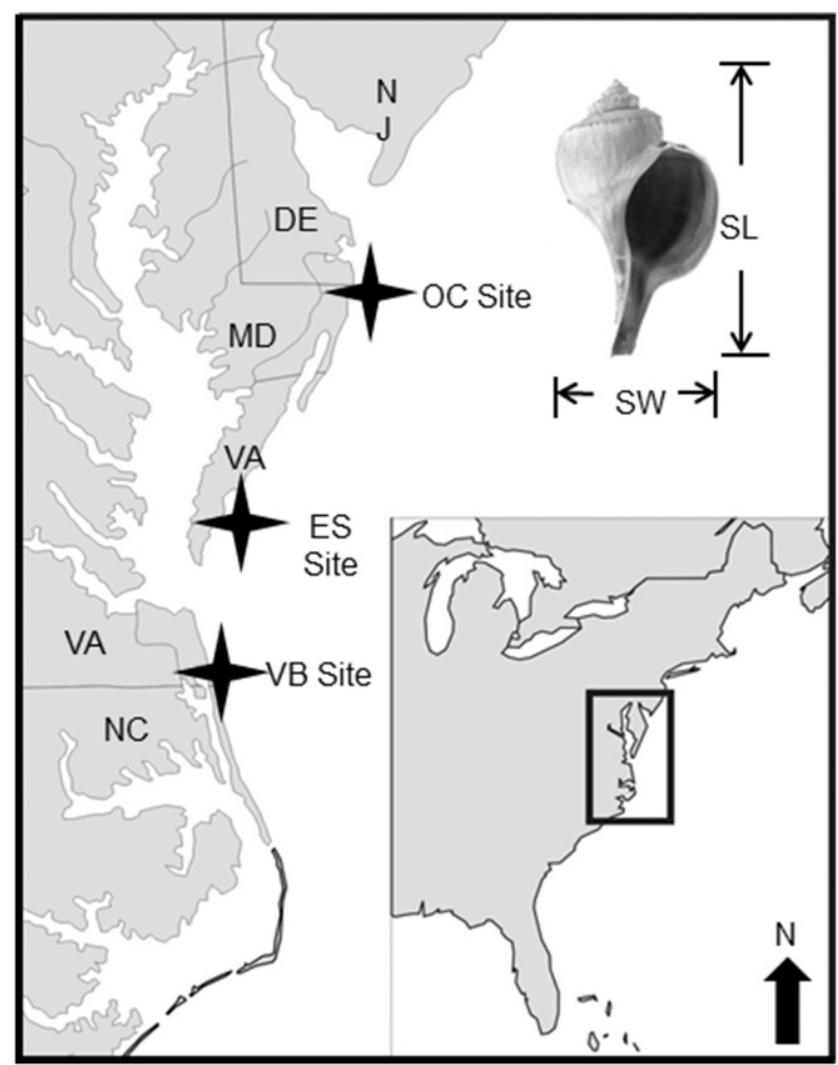

Figure 1. Whelk (Busycotypus canalicutas) resource areas sampled; Maryland/Delaware boarder (OC), Eastern Shore of Virginia outside Hog Island Bay (ES), and off southern Virginia Beach, VA (VB). Whelk measurements: shell height (SL), shell width (SW). Channeled whelk current (2016) minimal landing size (MLS) for Mid-Atlantic States.

shell at the second whorl proximal to the aperture (ventral side) and in-line with coiling axis. The columellar muscle was separated from columella of the shell and gently removed. Frozen samples were thawed at room temperature for 3-4 h, with the bodies removed from the shell by first inserting a finger up through the aperture along the columella and detaching the columellar muscle from the shell. The body was removed from the shell by gently pulling with a twisting motion in the direction of whorl.

Sex was determined by the presence or absence of a penis. Penis measurement (nearest $0.1 \mathrm{~mm}$ ) was taken from the resting penis state (folded at right angle) from tip of penis to outside corner of the fold. Penis index (PI = penis length/SL) values were generated and used in the evaluation of male sexual maturity.

Total wet body, gonad, and digestive gland weights were measured to nearest $0.1 \mathrm{~g}$ to facilitate the calculation of a gonadosomatic index (GSI) and the yield of commercially landed product.

$$
\text { GSI }=\text { gonad weight } / \text { somatic weight } \times 100
$$

where the somatic weight was the total wet body weight minus the gonad weight.

Yield was calculated as the wet body weight minus gonad and digestive gland, but included the oviduct in females (though removed in commercial processing) and penis in males (which is 
part of commercially processed product). Whelk flesh yield data were collected by examining a subsample of the necropsied and live (fresh, nonfrozen) animals used for histological analysis. Using fresh animals better approximates the market product and reduces the potential bias that is a function of the freezing and thawing process.

Macroscopic assessments on secondary sex organs were used to aid in the assignment of sexual maturity. Gonad size, color, and texture were recorded for both sexes. In males, the visceral section of vas deferens (VD) was observed for coiling (convolution) and presence of sperm. Presence of these features indicates male sexual maturity. In large males, the anterior section of VD (prostate to penis) running across the dorsal body surface to the base of penis was routinely observed protruding from immediately below epithelial layer and was noted as a possible characteristic of maturity. In females, capsule gland (CG) size, color, and condition (flaccid, plump) were recorded as confirmatory of female sexual maturity.

Age estimation was initially evaluated by interpreting growth increments (annular rings) of both the operculum (the corneous plate that closes the opening of the shell when animal is retracted) and the statolith (calcium carbonate structures within gastropod sense organs used for equilibrium). Obtaining age estimate for Busycotypus canaliculatus was most easily performed counting opercula stria; however, results from a McNemar test of symmetry about the main diagonal using both methods revealed that more precise aging was obtained through annuli counts from sectioned statoliths. Operculum aging underestimated age in comparison with aging results from sectioned statolith; therefore, age estimation in this study is reported using sectioned statoliths. Statoliths (two per whelk) were recovered during whelk necropsy. Statoliths are located within statocysts embedded in the spongie connective tissue and related ganglia connectives posterior to each pedal ganglion. Statoliths were removed from the statocysts, rinsed with tap water to remove any tissue remnants, and stored in $85 \% \mathrm{ETOH}$ until mounted. Each statolith was removed from alcohol storage, allowed to dry at room temperature $\left(20^{\circ} \mathrm{C}\right)$, embedded in a drop of heated CrystalBond 509 resin placed on glass microscope slide, then sectioned in half by gently passing the resin-bound statolith over a progressively finer wet abrasive paper (600-1,200 grit) under a dissecting microscope until the center of statolith (nucleus) was reached. After sectioning, statoliths were rinsed with distilled water to remove sanding debris.

Two readers independently estimated the age of whelk without the knowledge of the associated SL by counting concentric annular rings $(100 \times$ magnification $)$ of the sectioned statoliths. Annual rings extend outward from an initial ring (settlement ring) which was validated to be laid down shortly after juvenile whelk emergence from egg casing (concurrent age methodology study). In this study, the term "ring" references the dark concentric band observed between light concentric bands in statoliths which represents the period of slow growth associated with temperature minima (Fig. 2). The annual periodicity of growth ring formation in whelk statoliths was validated in Nassarius reticulatus (Barroso et al. 2005, Richardson et al. 2005, Chatzinikolaou \& Richardson 2007). When age disagreement occurred between readers, both readers viewed samples together for consensus on a final age determination. If readers were still not in agreement, the sample was eliminated

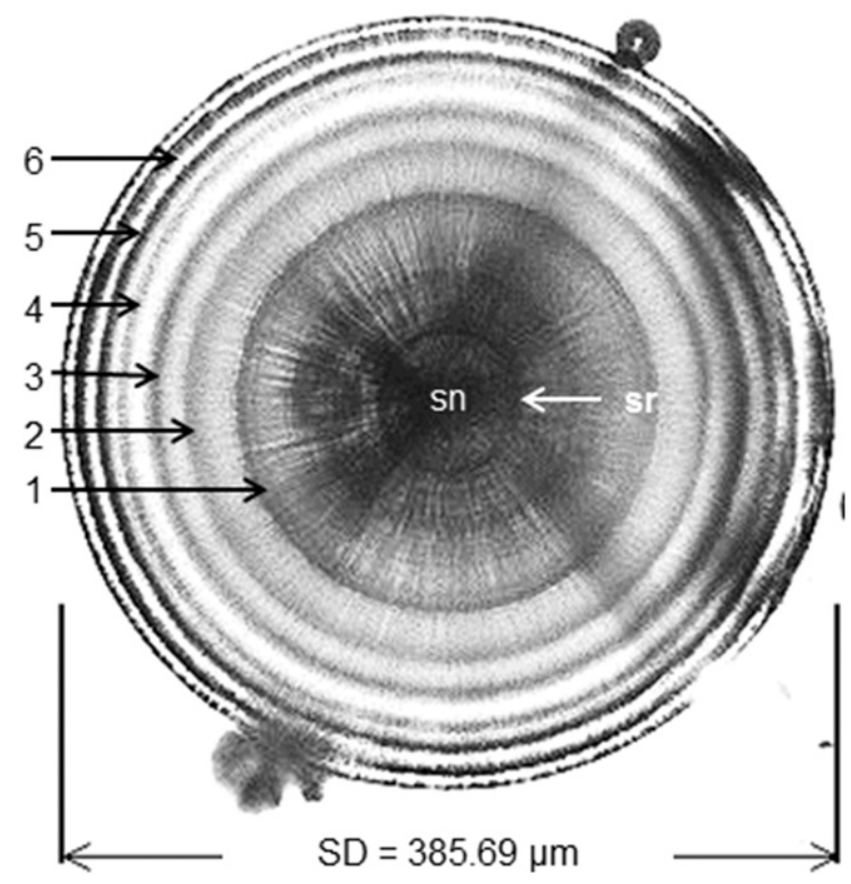

Figure 2. Statolith from Busycotypus canalicutas showing statolith nucleus (sn), settlement ring (sr), and numbered rings are used to estimate age for this study.

from the study. A McNemar test of symmetry about the main diagonal was used to test the null hypothesis that the readers were interchangeable against the alternative that there were systematic differences between the two readers.

\section{Growth}

An egg capsule string of Busycotypus canaliculatus containing live juveniles was collected from the beach at Buckroe, VA, during February 2010. The egg string consisted of empty capsules with the exception of three, which still contained live whelk. Within the capsules that contained whelk, one had the capsule pore still closed with 59 live juveniles inside. The other two capsules had opened pores and contained 40 and 22 live juveniles each, suggesting that hatching was nearly complete. Twelve juveniles randomly selected from capsules with open pores were measured (average SL $4.01 \pm 0.19 \mathrm{~mm}$ ). For future analyses, it was assumed that these animals represented age 0 . Statoliths from eight of these juveniles were recovered to document statolith diameter (average diameter $69.6 \pm 1.54 \mu \mathrm{m}$ sd) and to observe the deposition of any markings (nucleus, settlement rings) to aid age estimations. The remaining live juveniles were maintained in aquaria for subsequent growth evaluations.

Growth parameters for each sex at the three sampling sites (OC, ES, and VB) were estimated from observed age at length data (statolith readings) using the three parameter von Bertalanffy growth equation:

$$
=L_{\infty} *\left(1-e^{-k\left(t-t_{0}\right)}\right)
$$

where $L_{t}=$ whelk length in millimeters at age $t, L_{\infty}=$ asymptotic maximum length $(\mathrm{mm}), k=$ the growth rate 
parameter, and $t_{0}=$ the age of the animal at zero length. The three parameter function was fit to the data using the PROC NLMIXED in the SAS system v.9.2.

\section{Histology}

Gonads from male and female Busycotypus canaliculatus were processed histologically to evaluate female gonad synchrony, to identify stages of gonadal development, and to assess sexual maturity. Gonad samples (4-6 mm wide sections) were dissected from fresh, live whelk, placed in Davidson fixative, dehydrated in alcohol, and embedded in paraffin using standard histological methods. Samples were sectioned at $6 \mu \mathrm{m}$ thicknesses and stained with Harris hematoxylin and eosin Y. Gonad sections from three female and three male channeled whelk more than $160 \mathrm{~mm}$; shell length from all three collection sites were examined to determine if channeled whelk gonad development is synchronous (multiple developmental stages throughout the gonad) or asynchronous (only a single developmental stage throughout). Multiple visceral sections (gonad and digestive gland) were removed from the anterior, medial, and posterior areas of each gonad and evaluated. Synchrony within gonads was observed; therefore, all histological sampling was performed using medial section of the gonad. Gonad developmental stage was evaluated across whelk size (SL) groups following Ilano et al. (2003), Cledon et al. (2005), and Heude-Berthelin et al. (2011). Forty-one whelks were found with large orange-red, granular appearing masses associated with the digestive gland-gonad visceral area and histologically processed for parasitology interest only. These abnormal samples were not included in reproductive analysis.

Sexual maturity was determined by histological and macroscopic evaluations of reproductive organs as well as the gonad and penis indices plotted against the SL. Maturity ogives (cumulative histograms) were used to estimate the length at maturity (median SL at which $50 \%$ of the individuals are mature) and the penis length at maturity. Logistic regression with a binomial response $(0=$ immature, $1=$ mature $)$ was used to estimate the probability of sexual maturity as a function of SL. Post hoc hypothesis tests were used to determine the significance of various levels of factors tested (i.e., sex, area).

\section{RESULTS}

A total of 8,139 Busycotypus canaliculatus were collected between November 2009 and January 2011. During the November 2009 sampling, 1,920; 2,624 and 2,757 live whelks were collected from OC, ES, and VB resource areas, respectively. During the 2010 to 2011 seasonal sampling, a total of 838 whelks were collected: May $(n=107)$, June $(n=127)$, and November $(n=88) 2010$ at OC site; May $(n=168)$ and December $(n=98) 2010$ at ES site; and June $(n=116)$ and September $(n=3) 2010$ and January $(n=131) 2011$ at VB site. From combined sampling periods, representative animals were selected across the collected size categories for length-width relationship analysis $(1,490)$, the examination of histology with respect to reproductive biology (279), aging (214), and sexual maturity determinations (625). The largest whelk collected measured $230 \mathrm{~mm}$ (three females) and was recorded from OC. The smallest whelk collected from commercial sampling was $82 \mathrm{~mm}$ SL from OC. The smallest whelk collected from the field for this study was $58.2 \mathrm{~mm}$ SL (female) and $62.9 \mathrm{~mm}$ SL (male), which were collected alive on a beach in Ocean City, MD.

All of the 2009 sampled whelks were used for lengthfrequency distribution analysis (Fig. 3). Not included in this length-frequency analysis were $7.8 \%$ of OC, $9.0 \%$ of ES, and $6.3 \%$ of VB whelk landed on-board with broken siphonal canals, which were largely the result of culling practices on

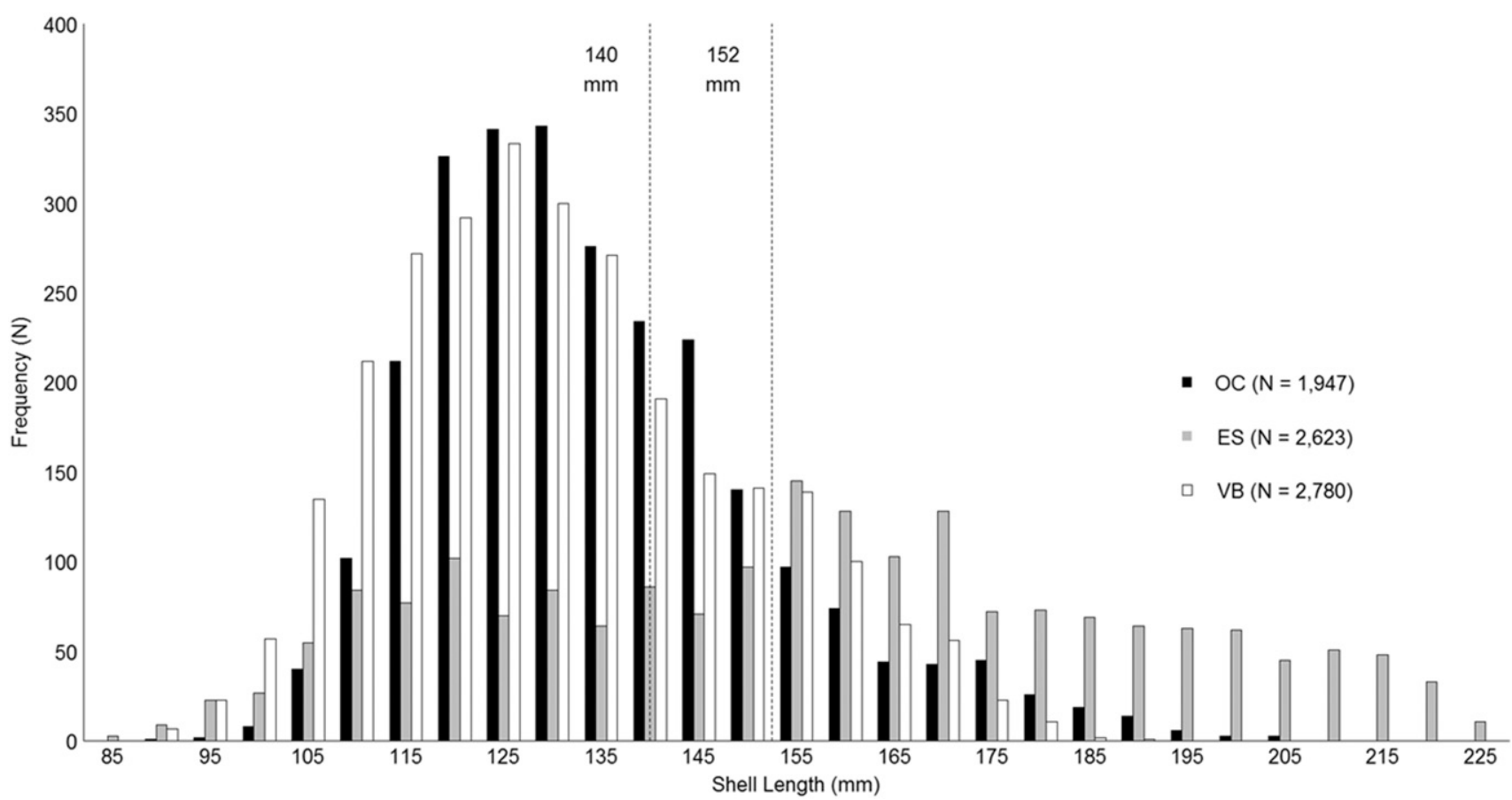

Figure 3. Length frequency distribution of Busycotypus canalicutas whelk from three commercially targeted populations (OC, ES, VB) in the MidAtlantic US. Vertical lines represent current minimal landing size (MLS) of 5.5" (139.7 mm) and 6" (152.4 mm). 
board commercial vessels (personal experience) and result in inaccurate length measurements. A one-way analysis of variance was used to test for differences in the mean length of whelks from the three resource areas. Multiple comparisons indicate that the mean length significantly differed between all three areas; however, the magnitude of the difference between OC $($ mean $=158.1 \mathrm{~mm}$, range $82-230 \mathrm{~mm}$ ) and the other two areas $[\mathrm{ES}($ mean $=137.6 \mathrm{~mm}$, range $97-209 \mathrm{~mm})$ and $\mathrm{VB}$ $($ mean $=132.2 \mathrm{~mm}$, range $90-190 \mathrm{~mm})]$ was greater than the magnitude of the difference between ES and VB. By sex within each resource area, mean SL was OC, female $152.6 \mathrm{~mm}(n=63)$, male $136.5 \mathrm{~mm}(n=117)$; ES, female $162.4 \mathrm{~mm}(n=63)$, male $137.5 \mathrm{~mm}(n=83)$; and VB, female $149.2 \mathrm{~mm}(n=134)$, male $125.6 \mathrm{~mm}(n=139)$. Percent sublegal (less than MLS for given area) whelk caught per resource area was highest in VB $(69 \%)$, followed by ES $(60.1 \%)$ and then OC $(43 \%)$.

The overall sex-ratio (M:F) of Busycotypus canaliculatus varied within each resource over all sampling periods (Table 1). In November 2009, sampling favored males in all areas, only slightly within VB (1.03:1), but more dominantly in both ES (1.32:1) and OC (1.31:1). Males dominated smaller whelk size in all areas, but more so in ES and VB. In spring and fall 2010 sampling, whelk distribution by sex remained similar to 2009 in $\mathrm{VB}$ and ES, but considerably more males were observed in OC (Fig. 4). Although a large increase in males was observed in 2010 OC samples, the average size of males remained similar $(131.5-136.5 \mathrm{~mm})$ at the size of sexual maturity. The average whelk size in both sexes from 2010 sampling was also observed to decrease from 2009 Fall sampling. Within all resource areas, larger whelks were predominantly females. A strong linear length-width relationship for $B$. canaliculatus was demonstrated for all areas (Fig. 5). The shell width in OC whelk increased slightly greater than ES and VB whelk (mm, inches) with increasing SL. There was no sexual dimorphism observed for whelk length-width relationship in OC and VB, the furthest geographically separated populations (Fig. 6).

\section{Yield}

Flesh yield versus SL relationships for Busycotypus canalicultaus were observed to vary slightly between areas (Fig. 7) with no sexual dimorphism observed in meat yield. Whelk from VB had the highest flesh yield over all sizes followed by ES then OC. This is supported by SL versus yield regression model

TABLE 1.

Sex ratio and average size (SL) of whelks within each resource area over all sampling periods.

\begin{tabular}{lccr}
\hline \hline $\begin{array}{c}\text { Resource area/ } \\
\text { sample period }\end{array}$ & $\begin{array}{c}\text { Avg. SL (mm) } \\
\text { male/female }\end{array}$ & $\begin{array}{c}\text { Sex ratio } \\
(\boldsymbol{M}: \boldsymbol{F})\end{array}$ & $\boldsymbol{n}$ \\
\hline VB fall 2009 & $136.5 / 152.6$ & $1.03: 1$ & 273 \\
VB spring 2010 & $117.2 / 137.1$ & $1.1: 1$ & 116 \\
VB fall 2010 & $124.3 / 129.8$ & $1.1: 1$ & 132 \\
ES fall 2009 & $137.5 / 162.4$ & $1.3: 1$ & 146 \\
ES spring 2010 & $125.3 / 140.6$ & $1.5: 1$ & 162 \\
ES fall 2010 & $140.6 / 154.5$ & $1.2: 1$ & 99 \\
OC fall 2009 & $136.5 / 152.6$ & $1.3: 1$ & 206 \\
OC spring 2010 & $136.2 / 143.3$ & $1.8: 1$ & 234 \\
OC fall 2010 & $131.5 / 145$ & $2.0: 1$ & 88 \\
\hline
\end{tabular}

results that indicated significant differences between each area. Model output indicates marginal significance $(P=0.0307)$ between VB and ES, whereas the differences between OC and the other two areas VB and ES were highly significant at $P<$ 0.0001 and $P=0.0034$, respectively. Yield at governing MLS for VB and ES (127 mm) was 72.8 and $68.6 \mathrm{~g}$, respectively. Yield of OC whelk at MLS $152.4 \mathrm{~mm}$ was $85.9 \mathrm{~g}$. Relative to variable MLS, an increase in flesh yield of $41 \%$ was observed in VB whelk going from MLS of 127 to $139.7 \mathrm{~mm}$ (5-5.5 in.) and $37.2 \%$ from 139.7 to $152.4 \mathrm{~mm}$ (5.5-6 in.). Yield nearly doubles (94\% yield increase) in VB whelk from MLS $127 \mathrm{~mm}(51.5 \mathrm{~g})$ to $152.4 \mathrm{~mm}(99.5 \mathrm{~g})$.

\section{Aging}

In total, statoliths from 213 Busycotypus canaliculatus were recovered for age estimation; 74 from OC, 50 from ES, and 89 from VB. Age estimates from sectioned statoliths are shown in Table 2 and ranged from 2 to $14 \mathrm{y}$. There was a significant difference between readers $\chi^{2}(1, N=285)=6.744, p=0.009$. Percent agreement between readers was $54.1 \% \pm 0 \mathrm{y}, 35.0 \% \pm 0$ $1 \mathrm{y}, 7.8 \% \pm 0-2 \mathrm{y}$, and $3.1 \%$ greater than or equal to $3 \mathrm{y}$.

\section{Growth}

Length at age data fit to von Bertalanffy growth curves are given for Busycotypus canaliculatus from each resource area (Fig. 8-sexes combined, Fig. 9-by sex). Growth rates of $B$. canaliculatus differed between the study areas, with VB whelk observed to grow faster (higher estimated $k$ ) than ES and OC, but reaching a smaller maximum length SL $\left(L_{\text {inf }}\right)$ than ES and OC (Table 3). Whelks from OC were observed to grow more slowly, but reach larger maximum sizes than VB or ES. Given the maximum observed SL from each area, the estimates for asymptotic maximum SL $\left(L_{\text {inf }}\right)$ were biologically reasonable for males and females from ES and VB, but overestimated for both sexes in OC. Overall, the size-at-age data indicate that male channeled whelk grow faster and reach a smaller maximum size than females. Sexual dimorphism with respect to growth was observed for each resource area.

\section{Sexual Maturity Stages}

In the fall of 2009, 146 whelks were processed for histological evaluation of gonad developmental stages; 57 from VB, 35 from ES, and 54 from OC. An additional 133 whelks were sampled from all three sites in the spring $(n=93)$ and fall $(n=22)$ of 2010 and January of $2011(n=18)$. These additional samples aided in the assessment of maturity because whelks from all three sites were determined to be at latter stages of gonadogenesis in sexually mature individuals. Not all maturity stages were represented in the sampling periods (resting and postspawning), and we report on the observations of gonad maturation and not seasonal reproductive cycle. Extension of the gonad in both sexes from the dorsal side of the digestive gland increased with whelk size and corresponded to advancing stages of maturation. In females, early gonadogenesis was observed in whelk where primary previtellogenic oocytes (oogonia) appeared in association with ovarian follicle germinal epithelium. Oocytes mature with the accumulation of vitellogen. In males, the testis contains seminiferous tubules from where spermatogenesis occurs. This cell differentiation process begins with spermatogonia (germ 


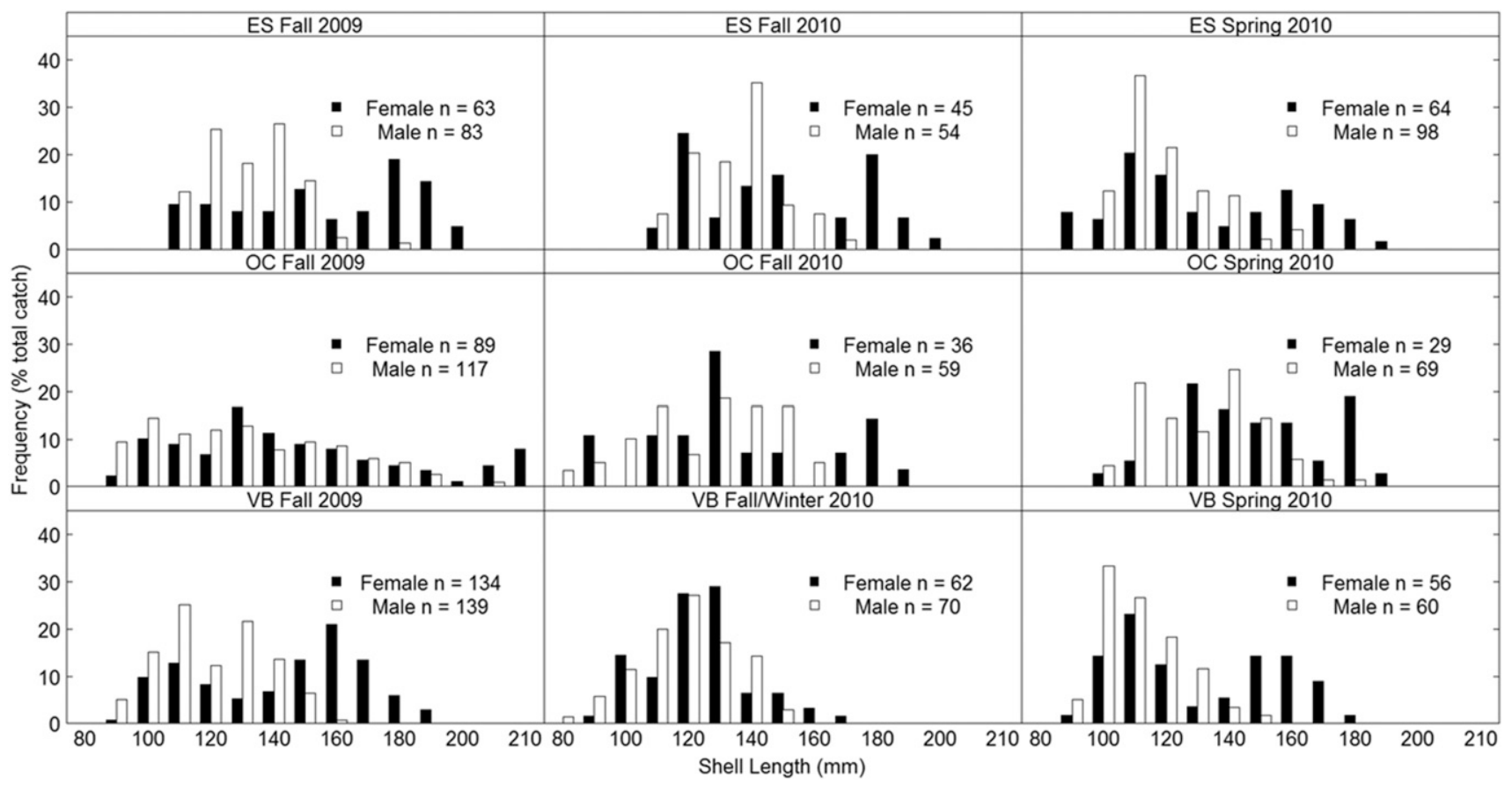

Figure 4. Sex ratio of Busycotypus canalicutas within each resource area over all sampling periods (fall 2009 to winter 2010).

cells) in the germinal epithelium of tubules undergoing maturational changes into mature spermatozoa (sperm). Histological stages of maturity are presented in Figure 10.

Immature

The female gonad first appears as an off-white and translucent band of tissue that begins to extend slightly outward from the digestive gland, accumulating mass as follicles thicken and oogonia develop into primary previtellogenic oocytes $(<10 \mu \mathrm{m})$ along the germinal epithelium (Fig. 10A). Previtellogenic oocytes possess a large nucleus/cytoplasm ratio with basophilic cytoplasm and granular nuclei. A significant amount of connective tissue is present separating ovarian follicles. The CG (nidamental gland) is thin, light beige, and nonconspicuous. The male gonad

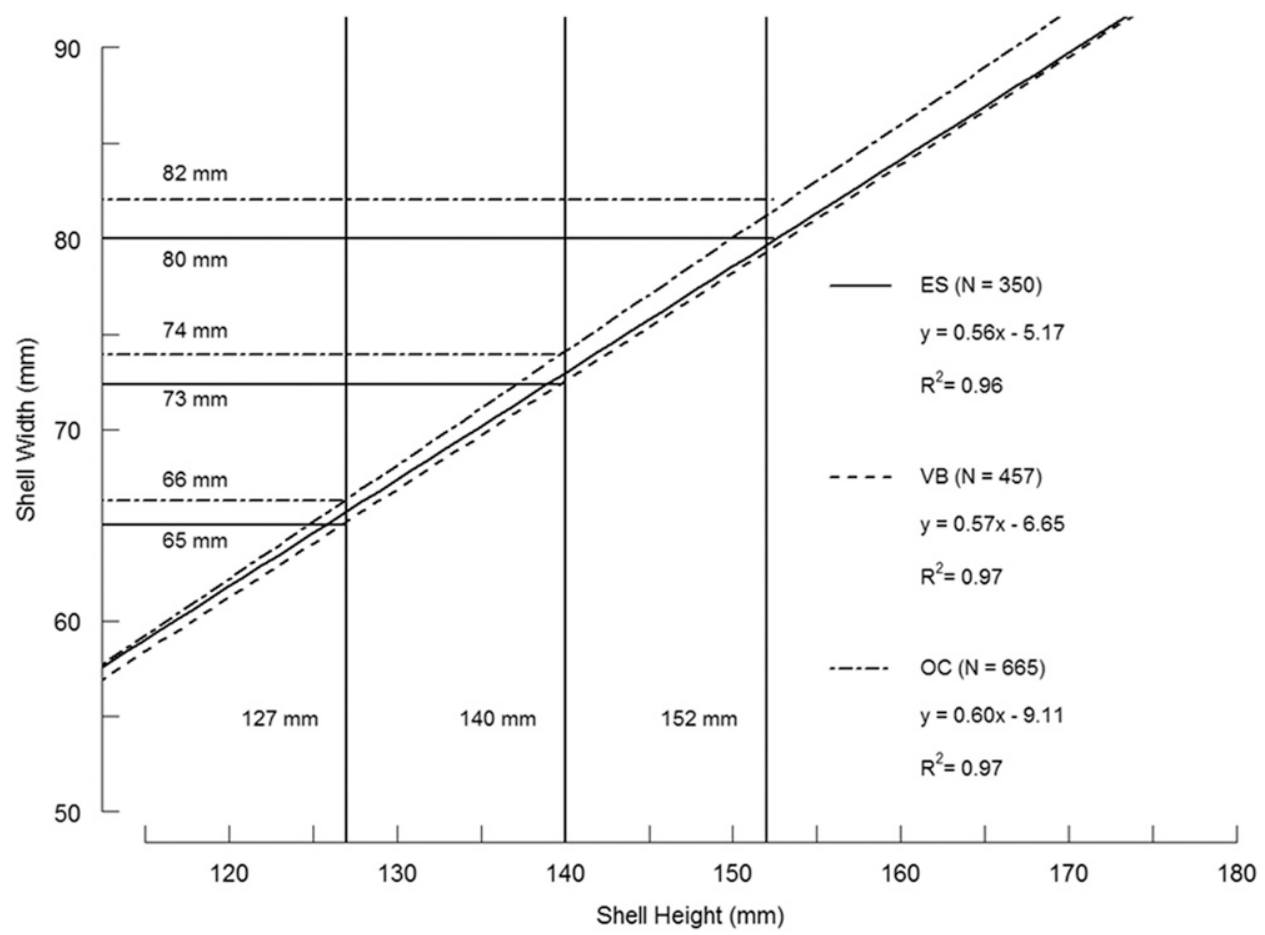

Figure 5. Relationship between shell length and shell width for Busycotypus canalicutas from three resource areas with resulting shell width (inches, mm) given current minimal landing size (MLS: 5", 5.5", and 6") in shell length. 


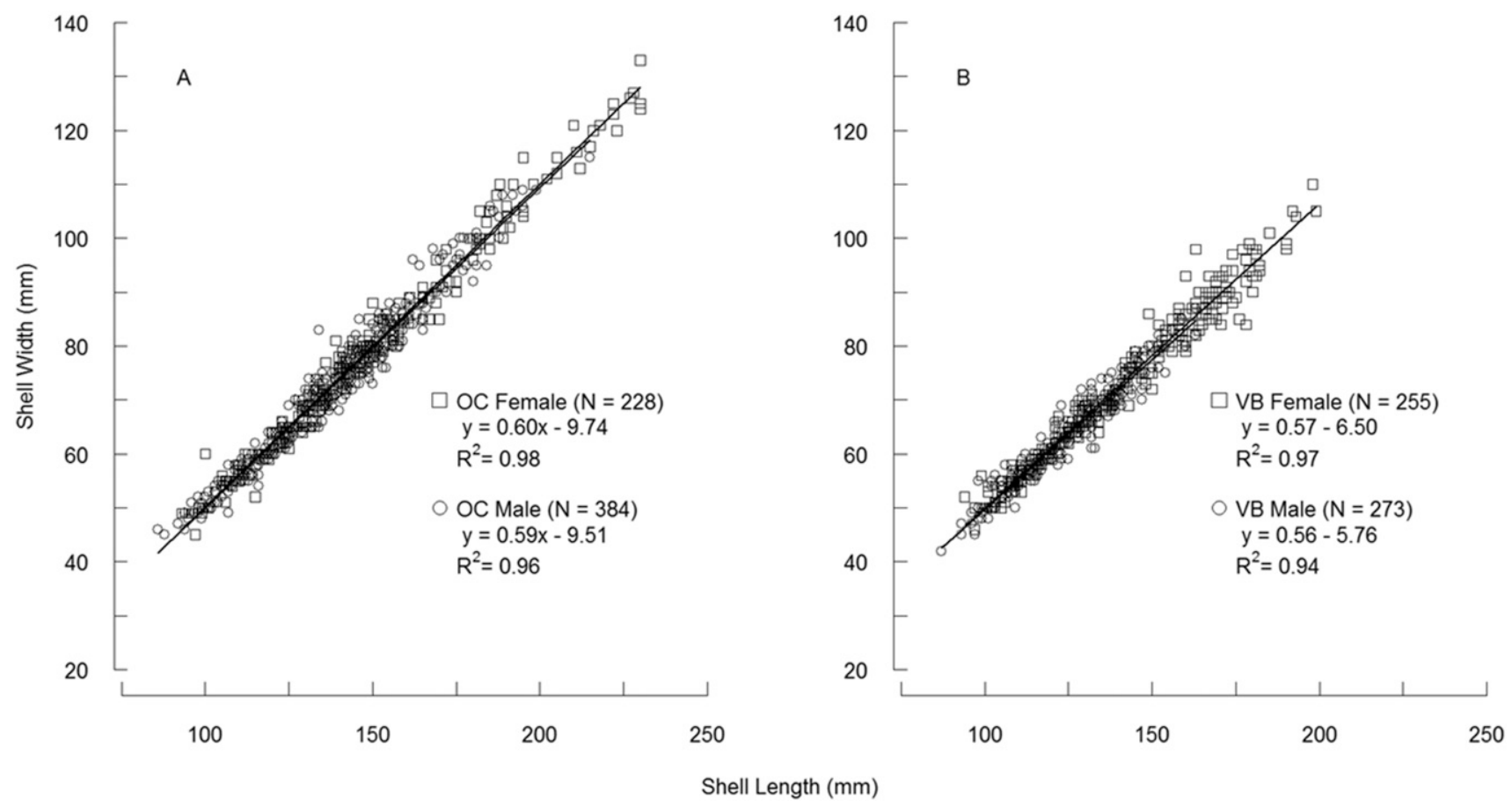

Figure 6. Shell length-shell width relationship by sex from OC (A) and VB (B) resource areas.

first appears as a thin, light band of tissue with few seminiferous tubules. The male gonad starts developing a light to pale orange color as spermatogenesis begins with tubule wall thickening. Only spermatogonia $(7-9 \mu \mathrm{m})$ are present at this stage. The VD is inconspicuous throughout its length.

\section{Maturing (Early to Late)}

This maturity stage consists of a wide developmental period centered on progression and extension of oocyte vitellogenesis in females and spermatogenesis in males. In females, the gonad enlarges with an increasing number of elongated ovarian follicles and vitellogenic oocytes that are characterized by cytoplasm accumulating yolk granules and prominent, round basophil nucleus (Fig. 10B, C). Yolk granules stained bright red with eosin become oval in shape within mature ova. In the early developing stage, follicles contain oocytes $(50-150 \mu \mathrm{m})$ with small, granular appearing yolk globules. With maturity, oocytes enlarge (300-500 $\mu \mathrm{m}$ diameter) with the accumulation of large

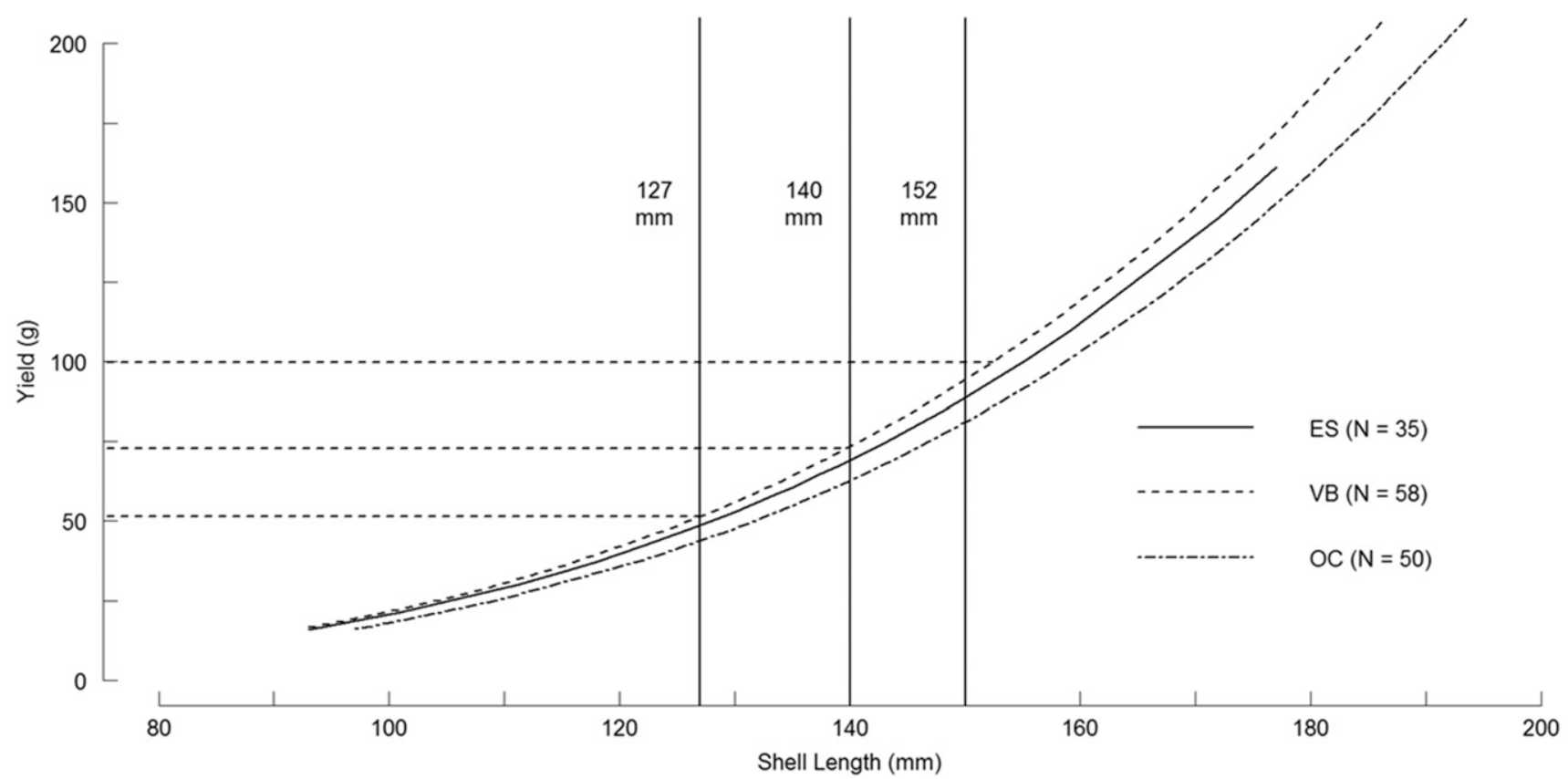

Figure 7. Flesh yield ( $g$ ) of fresh Busycotypus canalicutas from three resource areas. Vertical lines are current minimal landing sizes (MLS: 5", $\left.5.5^{\prime \prime}, 6^{\prime \prime}\right)$ in shell length. Horizontal dashed line is yield for VB area. 
TABLE 2.

Estimated age of Busycotypus canaliculatus tables generated from sectioned statoliths.

\begin{tabular}{|c|c|c|c|c|c|c|c|c|c|c|c|c|c|c|c|c|c|}
\hline \multirow[b]{2}{*}{ Location } & \multirow[b]{2}{*}{$\mathbf{0}$} & \multicolumn{16}{|c|}{ Age } \\
\hline & & 1 & 2 & 3 & 4 & 5 & 6 & 7 & 8 & 9 & 10 & 11 & 12 & 13 & 14 & 15 & 16 \\
\hline \multirow[t]{12}{*}{ VB } & Sexes combined & & & & & & & & & & & & & & & & \\
\hline & Ave SL (mm) & - & - & 103 & 117.3 & 135.6 & 146.8 & 168.5 & 183.2 & 195.5 & - & - & - & - & - & - & - \\
\hline & SD & - & - & 4.7 & 8.2 & 5.1 & 10.2 & 10.3 & 4.3 & 3.5 & - & - & - & - & - & - & - \\
\hline & $n$ & - & - & 13 & 26 & 11 & 15 & 15 & 5 & 4 & - & - & - & - & - & - & - \\
\hline & Females & & & & & & & & & & & & & & & & \\
\hline & Ave SL (mm) & - & - & 103.5 & 119.2 & 138 & 153 & 170.2 & 183.2 & 195.5 & - & - & - & - & - & - & - \\
\hline & $\mathrm{SD}$ & - & - & 5.7 & 6.2 & 5 & 9.7 & 10 & 4.3 & 3.5 & - & - & - & - & - & - & - \\
\hline & $n$ & - & - & 6 & 14 & 6 & 5 & 13 & 5 & 4 & - & - & - & - & - & - & - \\
\hline & Males & & & & & & & & & & & & & & & & \\
\hline & Ave SL (mm) & - & - & 102.5 & 115 & 132.8 & 143.7 & 161 & - & - & - & - & - & - & - & - & - \\
\hline & $\mathrm{SD}$ & - & - & 4 & 9.8 & 3.8 & 9.4 & 2.8 & - & - & - & - & - & - & - & - & - \\
\hline & $n$ & - & - & 7 & 12 & 5 & 10 & 2 & - & - & - & - & - & - & - & - & - \\
\hline \multirow[t]{12}{*}{ ES } & Sexes combined & & & & & & & & & & & & & & & & \\
\hline & Ave SL (mm) & - & - & - & 115 & 127.57 & 132 & 141.28 & 161 & 177.33 & 175.5 & 189.75 & 202 & 198 & 210 & - & 210 \\
\hline & $\mathrm{SD}$ & - & - & - & 2.5 & 4.7 & 5.6 & 6.7 & 9.2 & 10.9 & 14.8 & 6.1 & - & - & - & - & - \\
\hline & $n$ & - & - & - & 5 & 7 & 2 & 7 & 13 & 6 & 2 & 4 & 1 & 1 & 1 & - & 1 \\
\hline & Females & & & & & & & & & & & & & & & & \\
\hline & Ave SL (mm) & - & - & - & 114 & 129.5 & - & 142.2 & 164.77 & 181.2 & 186 & 192.3 & 202 & - & 210 & - & 210 \\
\hline & $\mathrm{SD}$ & - & - & - & 2.6 & 4.9 & - & 4.9 & 8.4 & 6.1 & - & 4 & - & - & - & - & - \\
\hline & $n$ & - & - & - & 3 & 2 & - & 2 & 9 & 5 & 1 & 3 & - & - & 1 & - & 1 \\
\hline & Males & & & & & & & & & & & & & & & & \\
\hline & Ave SL (mm) & - & - & - & 116.5 & 126.8 & 132 & 140.8 & 153.5 & 158 & 165 & 182 & - & - & - & - & - \\
\hline & $\mathrm{SD}$ & - & - & - & 2.1 & 5 & 5.6 & 7.8 & 5.8 & - & - & - & - & - & - & - & - \\
\hline & $n$ & - & - & - & 2 & 5 & 2 & 5 & 4 & 1 & 1 & 1 & - & - & - & - & - \\
\hline \multirow[t]{12}{*}{$\mathrm{OC}$} & Sexes combined & & & & & & & & & & & & & & & & \\
\hline & Ave SL (mm) & 48 & 60.5 & 98 & 102.3 & 122.5 & 136.5 & 142.8 & 163.1 & 186.2 & 193.3 & 198 & 210 & - & 230 & - & - \\
\hline & $\mathrm{SD}$ & - & 3.5 & - & 7.5 & 6.5 & 3.1 & 5.3 & 10.3 & 7.5 & 8.8 & - & 17.5 & - & 0 & - & - \\
\hline & $n$ & 1 & 2 & 1 & 13 & 10 & 4 & 8 & 17 & 5 & 7 & 1 & 3 & - & 2 & - & - \\
\hline & Females & & & & & & & & & & & & & & & & \\
\hline & Ave SL (mm) & 48 & 58 & 98 & 105 & 126.25 & - & 144.5 & 168 & 190 & 198.33 & 198 & 219 & - & 230 & - & - \\
\hline & $\mathrm{SD}$ & - & - & - & 9.1 & 5.1 & - & 3.7 & 5 & 12.7 & 10.4 & - & 11.3 & - & 0 & - & - \\
\hline & $n$ & 1 & 1 & 1 & 3 & 4 & - & 4 & 4 & 2 & 3 & 1 & 2 & - & 2 & - & - \\
\hline & Males & & & & & & & & & & & & & & & & \\
\hline & Ave SL (mm) & - & 63 & - & 101.5 & 120 & 136.5 & 141.25 & 161.61 & 183.66 & 192.33 & - & 192 & - & - & - & - \\
\hline & $\mathrm{SD}$ & - & - & - & 7.3 & 6.6 & 3.1 & 6.6 & 11.1 & 3.2 & 3 & - & - & - & - & - & - \\
\hline & $n$ & - & 1 & - & 10 & 6 & 4 & 4 & 13 & 3 & 3 & - & 1 & - & - & - & - \\
\hline
\end{tabular}

Age estimates are reported by sex and with sexes combined.

(20-30 $\mu \mathrm{m})$ yolk granules (globules). The accumulation rate, however, was not observed to be at the same rate, with various stages of oocyte vitellogenisis observed within follicles. Connective tissue remains significant and distributed between follicles, with the connective tissue-follicle ratio decreasing with maturity. At this stage, the female gonad is a light, pale orange in color that changes to yellow-brown as maturity progresses. Macroscopically, the enlarging follicles begin to give the gonad a coarser texture, becoming slightly granular as the whelk approaches maturity. The CG is beige in color and flaccid in structure, but firm as it enlarges with maturity with the glandular tissue inside becoming bright white in color.

In the early stage of male gonad maturation, only sperm precursors (spermatogonia, spermatocytes, spermatids) are observed. As maturity progresses, all development stages of spermatogenesis are observed with zones of spermatogonia, spermatocytes (4-6 $\mu \mathrm{m})$, spermatids (elongated cells $\sim 2 \times 8 \mu \mathrm{m}$ ), and some spermatozoa (sperm) when nearing maturity, extending from the tubule wall to the lumen (Fig. 10F). With maturity, a larger proportion of tubule's are observed containing mature spermatozoa. The visceral section of VD is visible on the ventral side of the digestive gland and appears as a very narrow, straight tube in immature whelk, and this structure subsequently thickens and becomes convoluted (coiled) as maturity is reached. Maturing male gonad color ranges from pale orange to orange.

\section{Mature}

Female and male gonads become plump, fully extended laterally and longitudinally from the digestive gland. Ovarian follicles in mature female gonads are compacted, cuboidal in shape (in transverse section) with mature oocytes (ova) filled with large (300-500 $\mu \mathrm{m}$, oval-shaped yolk (vitellus) globules (Fig. 10D, H). A few smaller oocytes in earlier stages of vitellogenesis may be present, but were observed to largely occupy the dorsal periphery of gonad. At late maturation, ova nuclei become inconspicuous as yolk globules dominate ova cytoplasm and individual ova become difficult to distinguish. 


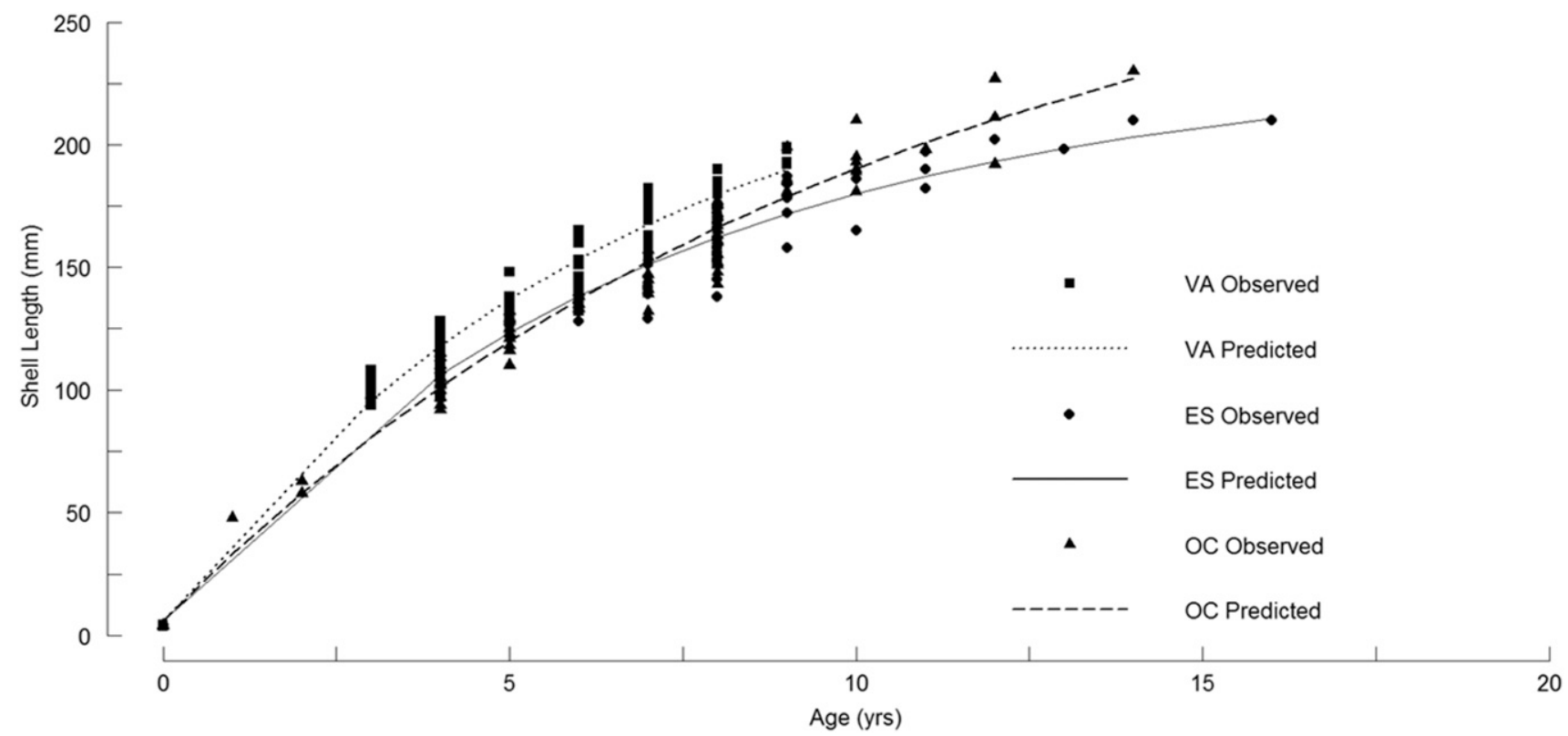

Figure 8. Length at age data for three Busycotypus canalicutas resource areas in the Mid-Atlantic with fitted von Bertalanffy growth curves. Age estimates from sectioned statoliths, sexes combined.

Minimal connective tissue is present in interfollicle space. Ripe female gonads macroscopically range from pale orange to yellowish-brown in color and appear granular as viewed through an increasingly thinning germinal epithelium. When ruptured, elongated follicles are observed to be arranged in columns extending outward from the digestive gland. The CG is large and plump, lightening in color by underlining bright white glandular tissue observed through a thinning gland epithelial.

In the mature male gonad, seminiferous tubules still contain all developing stages of reproductive cells, but most tubules become full of mature spermatozoa accumulating in dense masses in the lumen. With all stages of spermatogenesis represented, continuous and/or protracted production of mature sperm is suggested. The visceral section of the VD becomes highly convoluted (coiled) along the digestive gland, with convolution frequently observed to progress from the gonad anteriorly toward the penis as maturity progresses. If ruptured, mature sperm (spermatozoa) freely flows from the VD. The most anterior section of the VD is often visible on large mature whelk running along the dorsal surface (immediately below epithelial layer) of the body to the base of the penis. At this stage, the gonad color darkens to an orange-red. The penis size
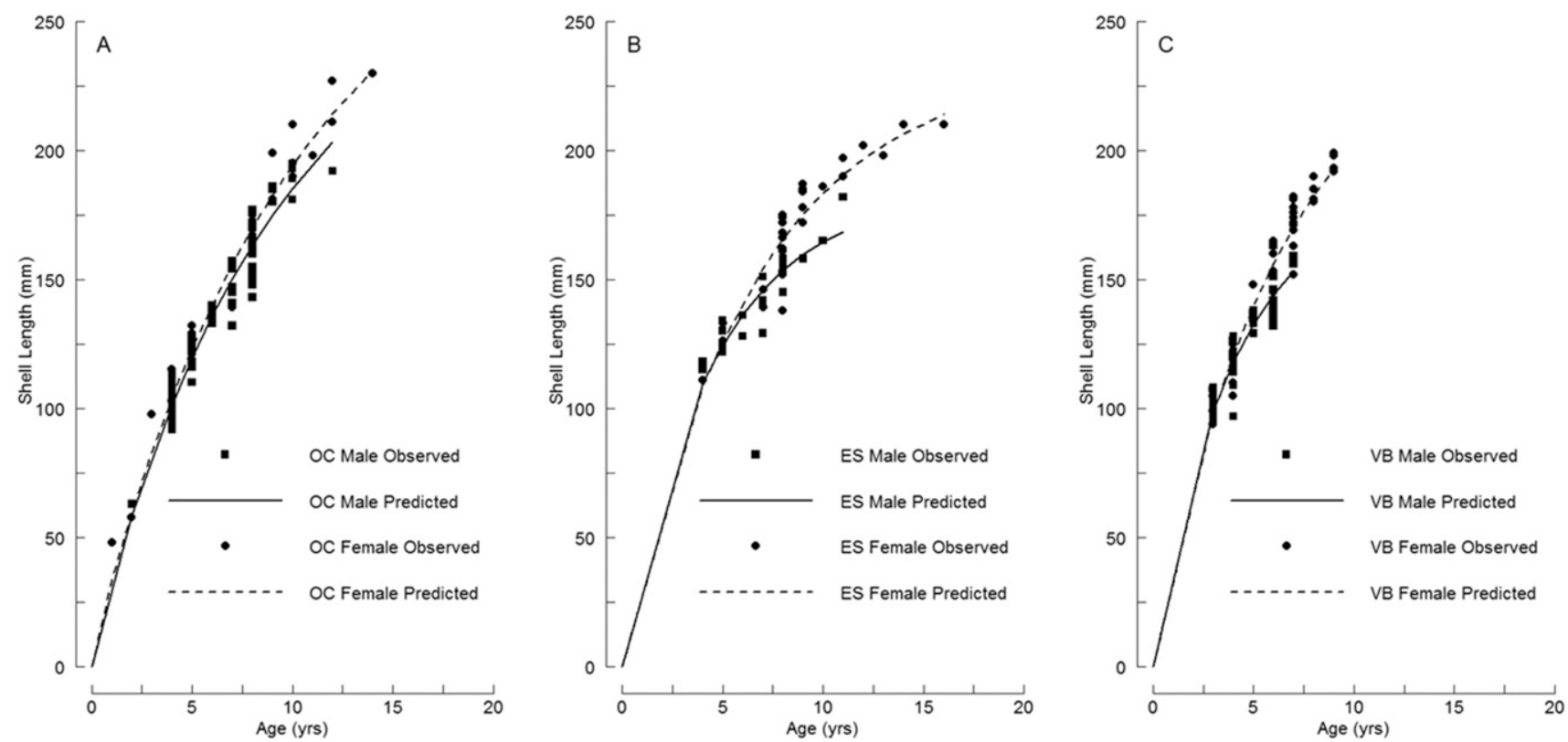

Figure 9. Length at age growth curves by sex from commercially targeted Busycotypus canalicutas populations in the Mid-Atlantic: OC (A), ES (B), and VB (C). Age estimates from sectioned statoliths. 
TABLE 3.

Estimated von Bertalanffy growth equation parameters for male and female Busycotypus canaliculatus from three sampling regions.

\begin{tabular}{llccc}
\hline \hline Resource area & Sex & $\boldsymbol{L}_{\infty}$ & $\boldsymbol{k}$ & $\boldsymbol{t}_{\mathbf{0}}$ \\
\hline Ocean City & Female & 304.45 & 0.100 & -0.178 \\
Ocean City & Male & 273.74 & 0.112 & -0.140 \\
Eastern Shore & Female & 235.53 & 0.151 & -0.122 \\
Eastern Shore & Male & 184.48 & 0.220 & -0.105 \\
Virginia Beach & Female & 255.23 & 0.155 & -0.116 \\
Virginia Beach & Male & 185.76 & 0.245 & -0.093 \\
\hline
\end{tabular}

Parameter estimates are shown with respect to estimated average maximum shell length $\left(L_{\infty}\right)$, growth rate coefficient $(k)$ and theoretical shell length at time zero $\left(t_{0}\right)$.

steadily increases through maturation, with a rapid increase in size observed as maturity is attained.

\section{Gonadosomatic Index}

An increase in the gonad weight was observed with the increasing SL in both sexes and correlated with advancing gametogenesis. This relationship was observed by plotting the GSI relative to SL (Fig. 11). Because sampling occurred only during two seasonal periods (fall 2009, spring 2010, and fall 2010), only snapshots of gonad condition at these time periods were obtained. The timing of sampling did not allow the comparison of gonad developmental stages between seasons within sexually mature whelks; however, the late stage of gametogenesis was present in sexually mature whelk from all sampling periods, thus allowing for assessment of a correlation between whelk sizes (SL), GSI, and biological sexual maturity. Overall GSI values by sex were similar between resource areas sampled, likely because of the similar environmental conditions (water temperature) in the respective environments at the time of sampling. Female GSI values for VB were observed to increase at smaller sizes (140-150 mm SL); however, GSI for ES females were observed to closely coincide with values for OC females, both showing increases starting between 155-160 mm SL (Fig. 11B, D, F). During the fall 2009 sampling, male GSI values were observed to increase starting at 115-120 mm SL for VB and ES males, but not until $\sim 130 \mathrm{~mm}$ SL for OC males (Fig. $11 \mathrm{~A}, \mathrm{C}, \mathrm{E})$. Mature sex products in whelk gonads were observed at GSI values more than 0.1 in females, and more than 0.2 in males. The GSI-SL relationships for both sexes from all sampling areas in spring 2010 and fall 2010 sampling were similar to fall 2009 GSI-SL relationships, suggesting spawning may occur in both fall and spring for Busycotypus canaliculatus.

\section{Penis Length}

The penis length progressively increased as a function of SL with a more rapid growth observed beginning between 110 and $115 \mathrm{~mm} \mathrm{SL}$ in VB and ES and between 120 and $125 \mathrm{~mm} \mathrm{SL}$ in OC males (Fig. 12). This rapid increase in penis length correlated with SL (PI range $0.10-0.15$, Fig. 13) in which rapid increases in GSI were observed and likely signify the onset of male sexual maturity for the respective areas.

Maturity stages for Busycotypus canaliculatus were defined by gonad histology, evaluations of secondary sex indices, and

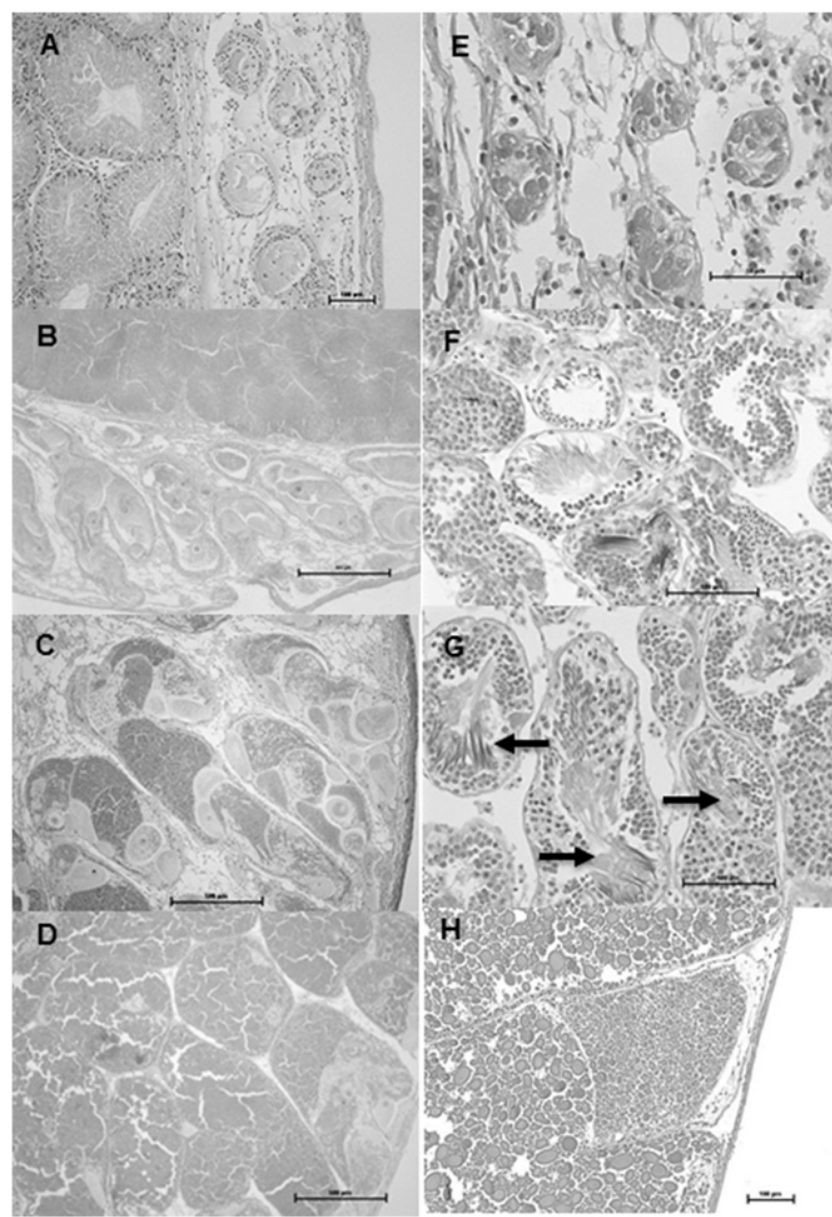

Figure 10. Photomicrographs of Busycotypus canalicutas showing histological stages of gonad development. Immature stage: female (A) showing only previtellogenic oocytes (oogonia) within follicles, and male (E) showing only spermatagonia in seminiferous tubules. Early maturing stage: female (B) showing previttellogenic and vitellogenic oocytes with prominent nuclei and small yolk granules. Late maturing stage: female (C) showing varying size vitellogenic oocytes with increasing number of mature ova with large yol granules, and male (F) showing late maturing stage with all reproductive cells present in tubules but only few with mature spermatozoa (arrows). Mature stage: female (D, H) showing large, cuboidal shaped follicles with ova $(300-500 \mu \mathrm{m})$ filled with large oval yolk granules, males $(G)$ showing most tubules with mature spermatogonia densely accumulating in tubles lumen (arrows). Scaled bars: (A, F-H) $100 \mu \mathrm{m}$, (B-D) $500 \mu \mathrm{m}$, and (E) $500 \mu \mathrm{m}$.

gross anatomy. These metrics are summarized in Table 4. Female sexual maturity was determined using the following criteria: GSI more than 0.2 ; ova $300-500 \mu \mathrm{m}$; $\mathrm{CG}$ medium to large, plump; and gonads granular in appearance. Male sexual maturity was determined using the following criteria: GSI more than 0.2; VD convoluted with sperm present; and PI greater than or equal to 0.15 . The smallest mature and the largest immature whelk found in this study is reported in Table 5.

\section{Maturity Ogives}

The relationship between size and sexual maturity is depicted by maturity ogives for male and female Busycotypus canaliculatus from all three resource areas (Fig. 14). The predicted median SL at $50 \%$ maturity $\left(L_{50}\right)$ for male and female with 

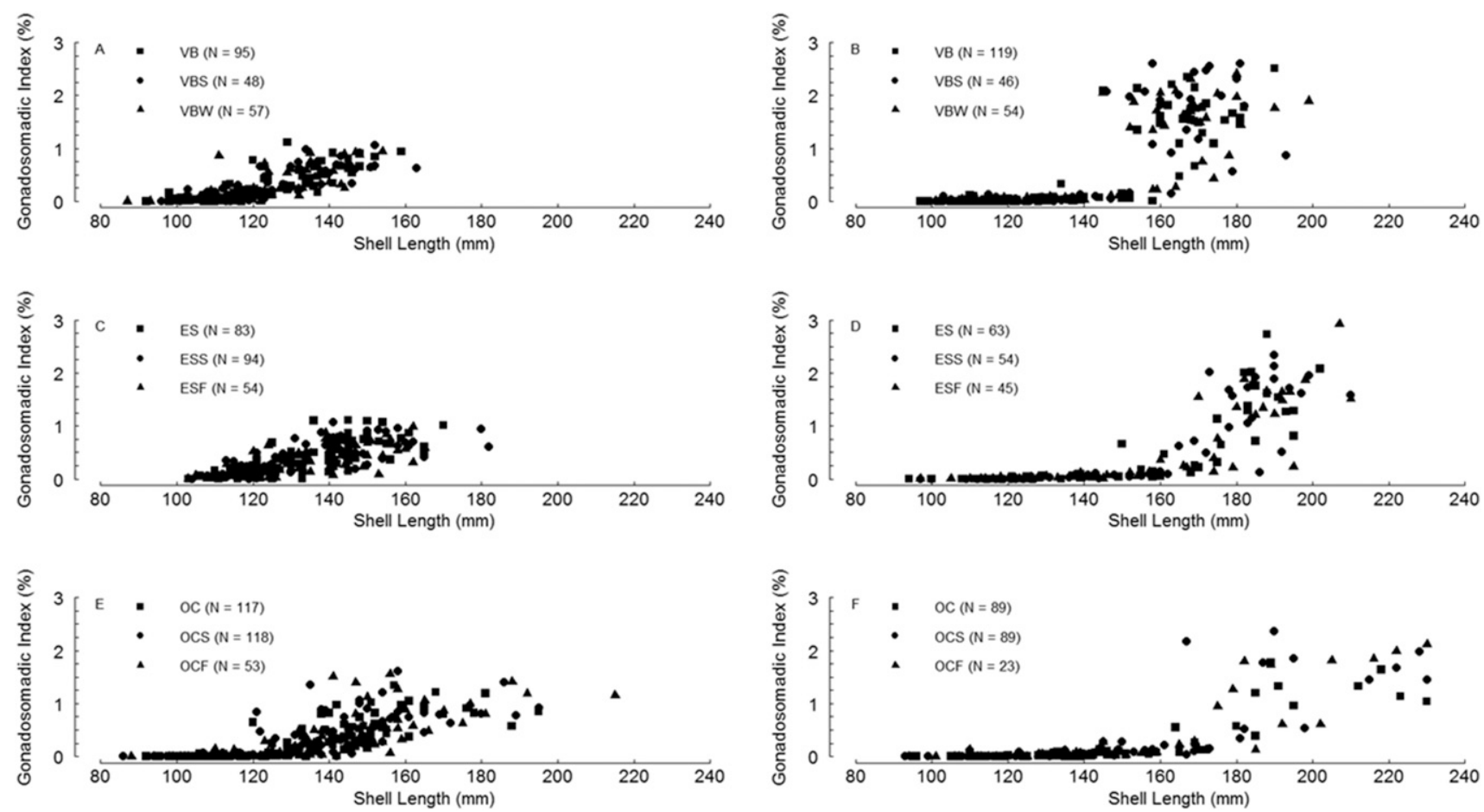

Figure 11. Seasonal gonadosomatic index by resource area and sex. Males (A, C, E) and females (B, D, F). OC = fall 2009; VBS, ESS, OCS = spring 2010; VBF, ESF, OCF = fall 2010.

bootstrap 95\% confidence intervals (Efron \& Tibshirani 1993) is shown in Table 6 for all areas. Results suggest that males reach sexual maturity at smaller SL than females within each area. Based on nonoverlapping confidence intervals of the Bootstrap $L_{50}$, as well as multiple contrasts generated from the logistic regression models, significant differences in size at maturity within areas were observed. Males from OC matured at a significantly greater SL $\left(L_{50}=134.05 \mathrm{~mm}\right)$ than both ES $\left(L_{50}=122.51 \mathrm{~mm}\right)$ and VB $\left(L_{50}=121.03 \mathrm{~mm}\right)$ males. Females from VB $\left(L_{50}=149.21 \mathrm{~mm}\right)$ matured at a significantly smaller SL than $\operatorname{ES}\left(L_{50}=157.65 \mathrm{~mm}\right)$ and OC $\left(L_{50}=159.28 \mathrm{~mm}\right)$ females. The penis length at maturity was predicted by a maturity ogive for males from each resource area (Fig. 15). The predicted penis length at $50 \%$ maturity was $18.8 \mathrm{~mm}$ for ES

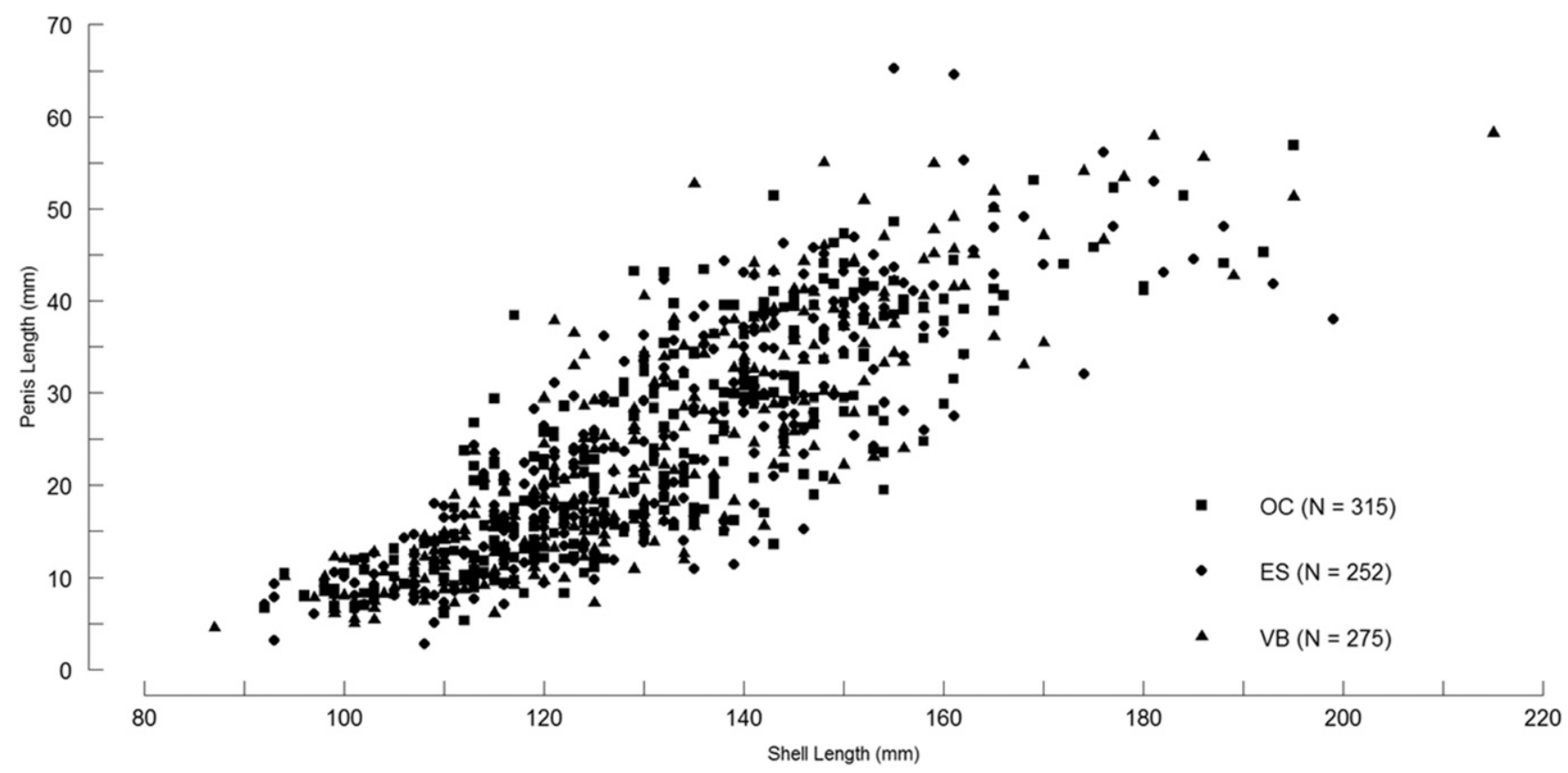

Figure 12. Male penis length-shell length relationship by area. 


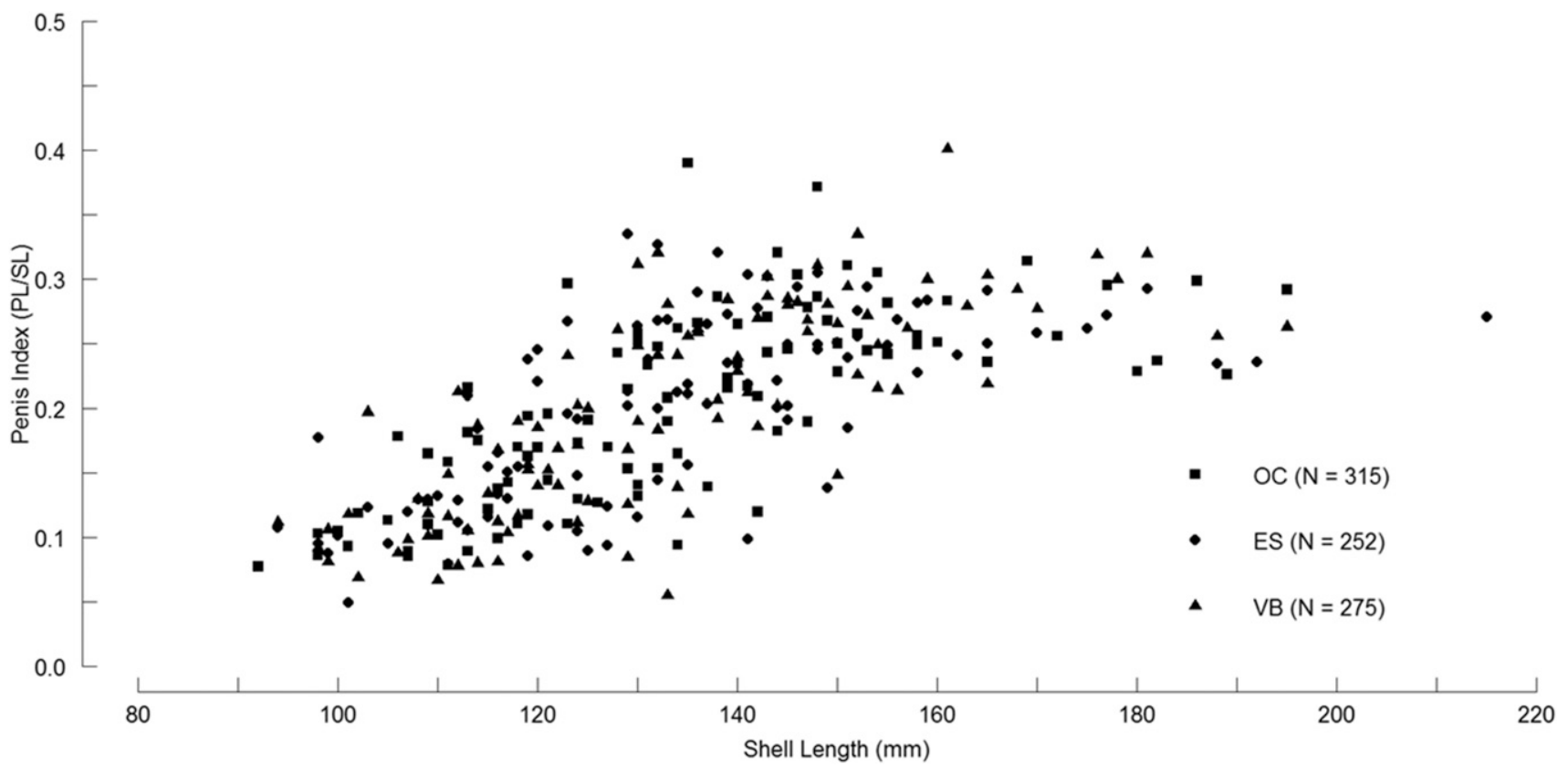

Figure 13. Relationship between shell length and penis index for male Busycotypus canalicutas whelks from the three resource areas.

males, $21.2 \mathrm{~mm}$ for OC males, $22.1 \mathrm{~mm}$ for VB males, and 21.1 for males from all areas combined.

\section{DISCUSSION}

Length frequency distributions of Busycotypus canaliculatus from the VB and ES sampling areas were very similar in structure, but quite different from the OC sample. Whelk from VB and ES showed a unimodal distribution whereas the OC population showed a bimodal distribution. The single peaks in length-frequency distribution from ES (125-135 mm) and VB $(120-135 \mathrm{~mm})$ areas were less than the MLS for that region $(139.7 \mathrm{~mm})$. The smaller peak $(115-130 \mathrm{~mm})$ of the OC distribution corresponded to a SL lower than the MLS (152.4 mm) for that region, whereas the larger peak $(155-165 \mathrm{~mm})$ was larger than the OC MLS. Both unimodal and bimodal size distributions within commercially targeted whelk populations from different geographic locations have been reported (Fahy et al. 2000, Shelmerdine et al. 2007) and are suggestive of differences in growth and mortality (fishing and natural). The first peak of

TABLE 4.

Definition of maturity stages of Busycotypus canaliculatus.

\begin{tabular}{|c|c|c|c|}
\hline & Immature & Maturing & Mature \\
\hline \multirow[t]{4}{*}{ Male } & GSI $<0.1$ & GSI $0.1-0.2$ & GSI $>0.2$ \\
\hline & $\mathrm{PI}<0.1$ & PI $0.1-0.15$ & $\mathrm{PI}>0.15$ \\
\hline & $\begin{array}{l}\text { VD; visceral section thin, straight, } \\
\text { and anterior section not visible }\end{array}$ & $\begin{array}{l}\text { VD; visceral section thickening, slight coiling } \\
\text { during late stage, and anterior section } \\
\text { becoming slightly visible }\end{array}$ & $\begin{array}{l}\text { VD; visceral section highly coiled, } \\
\text { full of sperm, and anterior section } \\
\text { prominently visible on body surface }\end{array}$ \\
\hline & Gonad color light/pale orange & Gonad color pale orange & Gonad color dark orange/red \\
\hline \multirow[t]{4}{*}{ Female } & GSI $<0.01$ & GSI $0.01-0.1$ & GSI $>0.1$ \\
\hline & $\begin{array}{l}\text { Gonad mostly CT appearing as a } \\
\text { light band of tissue; Follicles } \\
\text { small with previtellogenic } \\
\text { oocytes (oogonia) }<10 \mu \mathrm{m}\end{array}$ & $\begin{array}{l}\text { Early: follicles with significant CT between, } \\
\text { gonads lacking of texture, vitellogenic } \\
\text { oocytes } 50-150 \mu \mathrm{m} \text { with prominent nuclei } \\
\text { and small yolk granules. } \\
\text { Late: follicles expanding with increasing } \\
\text { number of large ova ( } 300-500 \mu \mathrm{m} \text { diameter) } \\
\text { with large oval yolk granules }(20-30 \mu \mathrm{m}), \\
\text { texture firming, and becoming granulated } \\
\text { in appearance }\end{array}$ & $\begin{array}{l}\text { Follicles columnar, densely packed } \\
\text { with ova }(300-500 \mu \mathrm{m}) \text { full of large, } \\
\text { oval yolk granules and inconspicuous } \\
\text { nuclei; gonads highly granular } \\
\text { in appearance }\end{array}$ \\
\hline & CG thin, beige, and nonconspicuous & $\begin{array}{l}\text { CG: early; small, beige, and flaccid } \\
\text { Late; medium, beige, and becoming firm }\end{array}$ & CG large, plump, and light beige \\
\hline & Gonad color off-white, translucent & $\begin{array}{l}\text { Gonad color light, pale orange progressing } \\
\text { to yellow/brown }\end{array}$ & $\begin{array}{l}\text { Gonad color ranging from orange-yellow } \\
\text { to yellow-brown }\end{array}$ \\
\hline
\end{tabular}

CG, capsule gland; CT, connective tissue; GSI, gonadosomatic index; PI, penis index; VD, vas deferens. 
TABLE 5.

Smallest mature and largest immature whelk recorded with maturity measures.

\begin{tabular}{cccc}
\hline \hline Area & Sex & Smallest mature & Largest immature \\
\hline Ocean City & Male & $\mathrm{SL}=122 \mathrm{~mm}, \mathrm{GSI}=$ & $\mathrm{SL}=142 \mathrm{~mm}, \mathrm{GSI}=$ \\
& & $0.221, \mathrm{PI}=0.15$, & $0.015, \mathrm{PI}=0.12$, \\
& & $\mathrm{PL}=19.8$ & $\mathrm{PL}=19.8$ \\
& Female & $\mathrm{SL}=144, \mathrm{GSI}=0.137$, & $\mathrm{SL}=159, \mathrm{GSI}=0.076$, \\
& & $\mathrm{CG}=$ medium $/$ & $\mathrm{CG}=$ medium/ \\
Eastern Shore & Male & $\mathrm{plump}$, firm & semiflaccid \\
& & $0.339, \mathrm{mI}=0.22$, & $0.089, \mathrm{PI}=0.14$, \\
& & $\mathrm{PL}=24.4$ & $\mathrm{PL}=17.1$ \\
& Female & $\mathrm{SL}=143, \mathrm{GSI}=$ & $\mathrm{SL}=122 \mathrm{~mm}, \mathrm{GSI}=$ \\
& & $0.101, \mathrm{CG}=\mathrm{small} /$ & $0.089, \mathrm{PI}=0.14$, \\
Virginia Beach & plump, firm & $\mathrm{PL}=17.1$ \\
& Male & $\mathrm{SL}=103 \mathrm{~mm}, \mathrm{GSI}=\mathrm{SL}=122 \mathrm{~mm}, \mathrm{GSI}=$ \\
& & $0.216, \mathrm{PI}=0.19$, & $0.089, \mathrm{PI}=0.14$, \\
& & $\mathrm{PL}=20.3$ & $\mathrm{PL}=17.1$ \\
& Female & $\mathrm{SL}=143, \mathrm{GSI}=0.102$, & $\mathrm{SL}=158, \mathrm{SI}=0.008$, \\
& & $\mathrm{CG}=$ medium $/$ & $\mathrm{CG}=$ medium/ \\
& & semifirm & flaccid \\
\hline
\end{tabular}

SL, shell length; GSI, gonadosomatic index; CG, capsule gland (relative size/condition); PI, penis index; PL, penis length.

the bimodal distribution observed in OC $(\sim 120 \mathrm{~mm}$, well below MLS) suggests large number of recruits followed by high mortality, with the second peak ( $\sim 160 \mathrm{~mm}$, above MLS) suggesting decrease in mortality with increase in size. The first peak shows potential for recruitment to the fishery, although at a size/age under that of the estimated sexual maturity. Unimodal distributions were observed in ES and VB with peaks $(\sim 120-135 \mathrm{~mm})$ less than MLS of $139.7 \mathrm{~mm}$ (5.5 in.) for that resource area. A unimodal distribution reflects high recruitment followed by high mortality, possibly from predation or fishing pressure. If

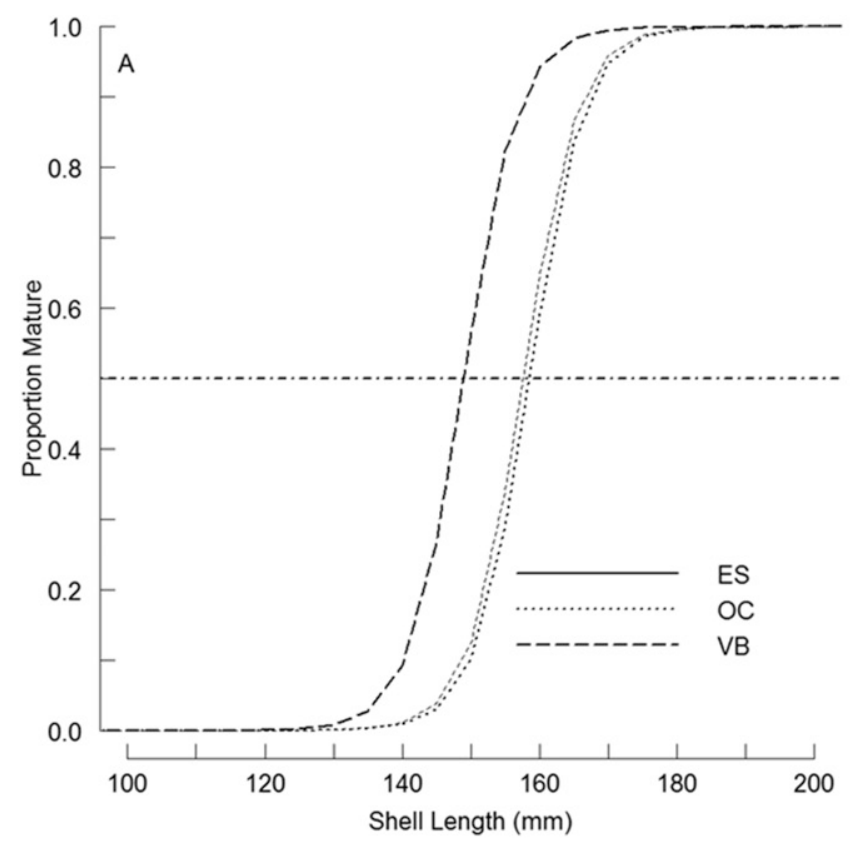

Figure 14. Maturity ogives for male (A) and female (B) Busycotypus canalicutas whelks by resource area. mortality was driven by higher predation then morphological differences, such as shell thickness (Thomas \& Himmelman 1988), would be expected in B. canaliculatus from these regions, but no such differences were observed. Greater fishing pressure, relative to smaller MLS in ES and VB may also contribute to high mortality. The strong similarity in whelk size distribution observed in ES and VB populations may suggest more synchronized spawning and recruitment than those observed in the OC population, possibly related to more similar environmental conditions shared by ES and VB. The similarity observed in gametogenesis occurring in both sexes (macroscopically and histologically) in all three resource areas in fall and spring periods (2009 to 2011), coupled with GSI's indicative of maturing and mature whelks, also suggests synchrony in gonadal development in both sexes of $B$. caniculatus over extended periods. With mature, ripe whelks present in both fall and spring seasons, multiple annual cohorts seem plausible. This life history strategy is not uncommon for molluscs that use a protracted spawning approach to hedge against environmental variability to improve the probability of reproductive success.

When length frequency distributions are viewed in $1 \mathrm{~mm}$ bin size (Fig. 16), the multiple peaks observed over SL are very distinct (high amplitude peaks with low amplitude troughs between), initially giving appearance of strong annual cohort recognition. Many of these peaks are also observed with a secondary peak with less amplitude. The relative strength and distance (length) between the peaks would suggest much slower growth than that determined in this study if representing annual cohorts. Multiple peaks over relatively short lengths suggest multiple annual cohorts. Cohort analysis using observed whelk frequency distributions can provide a means to visualize peaks in the distribution (Bhattacharya 1967). This approach bins over length intervals (i.e., 3 or $5 \mathrm{~mm}$ ) and subtracts the smaller SL bins from the adjacent larger bin to reduce the noise in the observed distribution. Resulting smoothed distributions yield major peaks and allowed for the identification of annual or intra-annual

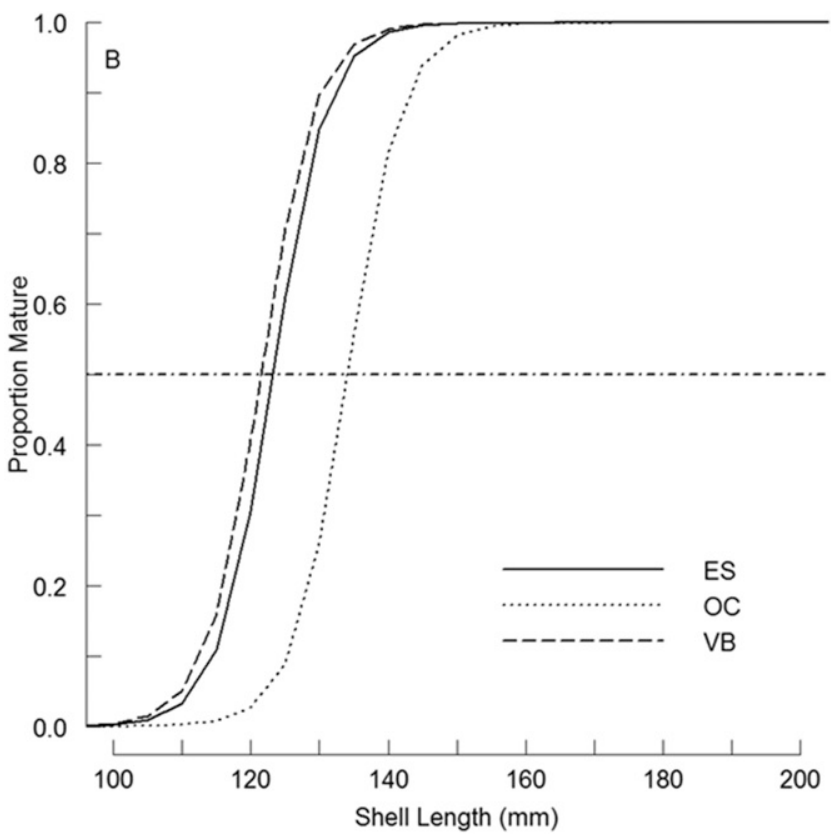


TABLE 6.

Predicted size at maturity by resource area and sex.

\begin{tabular}{llccc}
\hline \hline $\begin{array}{c}\text { Resource } \\
\text { area }\end{array}$ & Sex & $\begin{array}{c}\text { Size at } \\
\text { maturity }(\mathbf{m m})\end{array}$ & $\begin{array}{c}\text { Lower } \\
\mathbf{9 5 \%} \text { CI }\end{array}$ & $\begin{array}{c}\text { Upper } \\
\mathbf{9 5 \%} \text { CI }\end{array}$ \\
\hline Ocean City & Female & 159.28 & 153.09 & 165.25 \\
& Male & 134.05 & 130.57 & 137.26 \\
Eastern Shore & Female & 157.65 & 154.28 & 161.8 \\
& Male & 122.51 & 117.59 & 126.10 \\
Virginia Beach & Female & 149.21 & 145.17 & 153.03 \\
& Male & 121.03 & 118.91 & 123.02 \\
\hline
\end{tabular}

Bootstrapped $95 \%$ confidence limits are showed for each sex and resource area.

cohorts. These peaks matched the size ranges corresponding with whelk age estimates from this study (Fig. 17), further supporting the observation of multiple annual cohorts.

In Busycotypus canaliculatus with SL more than MLS of $139.7 \mathrm{~mm}$ (5.5 in.), $50.5 \%, 55.3 \%$, and $76 \%$ were females in OC, ES, and VB areas, respectively (fall 2009). In whelk with SL more than MLS of $152 \mathrm{~mm}$ (6 in.), 52.1\%, 74.1\%, and 95\% were females in OC, ES, and VB areas, respectively. Although the sex ratio $(M: F)$ was more similar within $\mathrm{VB}(1.03: 1)$ than ES (1.3:1) and OC (1.3:1) areas, significantly more females comprised older, larger whelk in VB than ES or OC. Size dimorphism between sexes in whelk has been widely reported (Magalhaes 1948, Dicosimo 1988, Anderson et al. 1989, Shalack 2007, Walker et al. 2008). With the largest whelk within a population dominated by females, the question of sequential protandrous hermaphroditism within this species arises. No evidence of this reproductive variation was observed within this study, with all male and female $B$. canaliculatus possessing respective sex organs and secondary sex characteristics throughout life stages of growth and development (i.e., gonochoristic). Predominance of smaller whelk may be due to

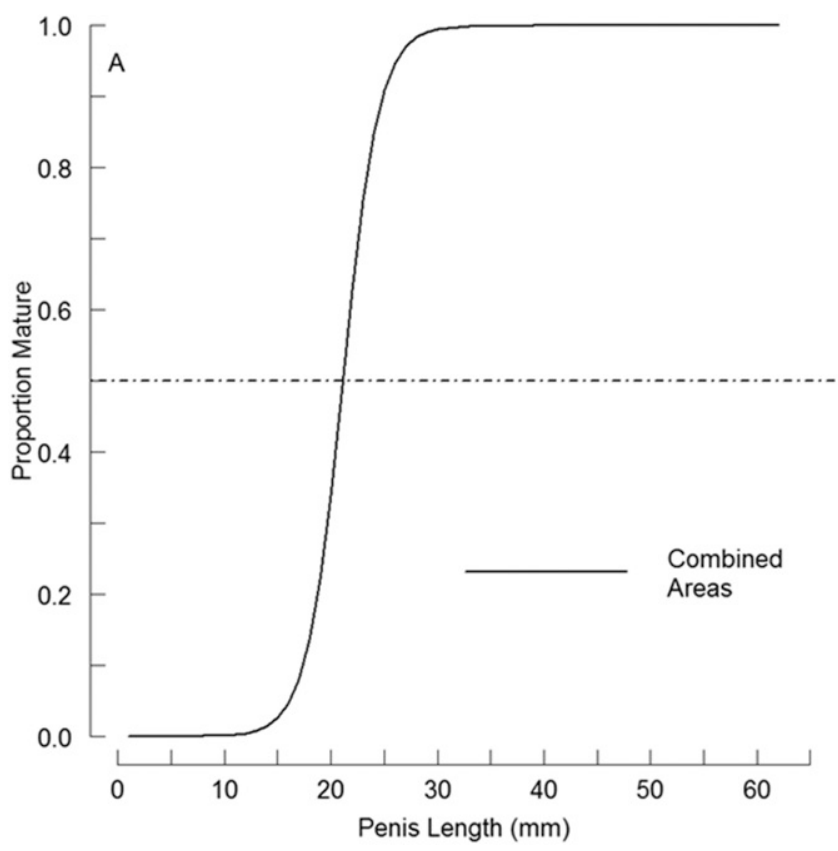

differences in growth rates and management measures (MLS) that favor larger whelk. Observed size dimorphism within these populations may also be a result of spatial and/or temporal variations at time of sampling. Habitat use within B. canaliculatus for any given life history parameter is poorly understood.

As in other carnivorous whelk, the possibility of sampling bias from selectivity of baited traps during periods of breeding and varying feeding rates between the sexes may exist (McQuinn et al. 1988, Power \& Keegan 2001). From spring and fall 2010 sampling, Busycotypus canaliculatus distribution by sex of harvested whelk from baited traps remained similar to fall 2009 sampling in VB and ES, but significantly more males were observed in OC. Although a significant increase in males was observed in OC 2010 samples, the average size of males remained similar at size of sexual maturity. Average whelk size in both sexes from the 2010 sampling was also observed to decrease from the 2009 fall sampling. With similar states of reproduction (GSI and histological evaluation) observed in both sexes from all areas and sampling periods in this study, attraction to baited traps, and therefore, sampling bias attributed to altered feeding rate associated with the state of reproduction, was not discernible.

Size at hatching (age 0) of Busycotypus canalicuatus in this study $(4.01 \pm 0.19 \mathrm{~mm} \mathrm{SL})$ agreed with size at hatching $(3.84 \pm$ $0.13 \mathrm{~mm} \mathrm{SL}$ ) reported by Harding (2011), providing reasonable confidence for including time 0 for growth model estimation. The term "settlement ring" references the signature on statoliths formed when planktotrophic larvae settle and metamorphose to the benthic juvenile forms. In B. canaliculatus, development to free crawling juveniles is completed within the egg capsule; hatching juveniles immediately adopt a benthic existence. In statoliths recovered from $B$. canaliculatus at the time of hatching, no settlement or hatching ring was observed, indicating that its formation occurs at some point after hatching and during transformation to benthic life. Observing average statolith diameter of juveniles on hatching $(69.6 \mu \mathrm{m}, n=8)$ and average settlement ring diameter of adult $B$. canaliculatus over

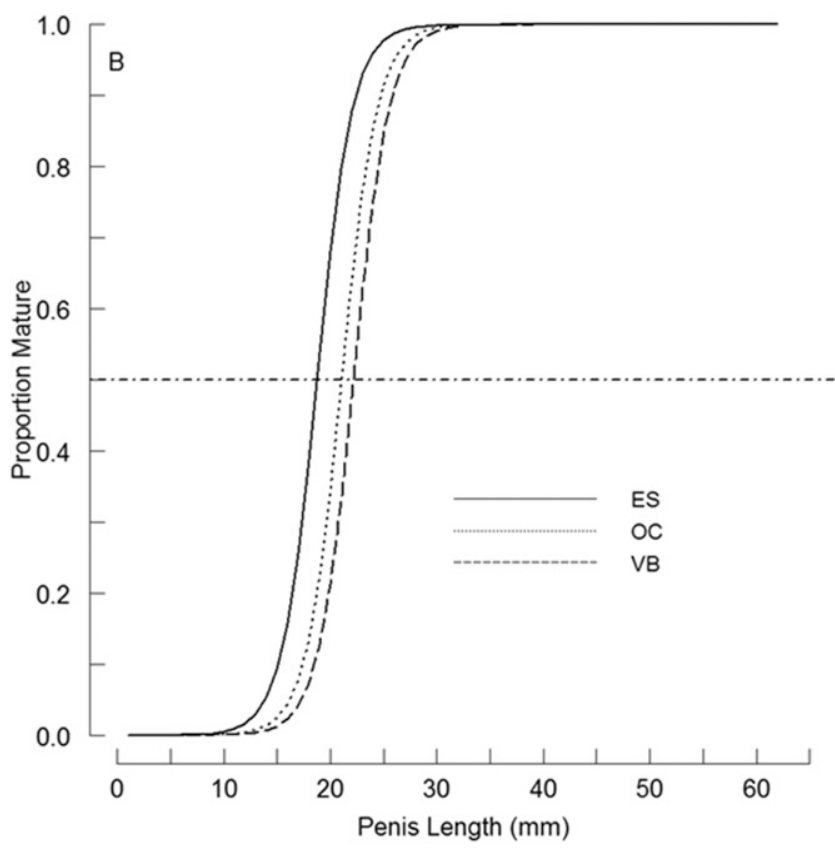

Figure 15. Maturity ogive of male Busycotypus canalicutas whelk penis length for all areas combined (A) and by areas (B). 


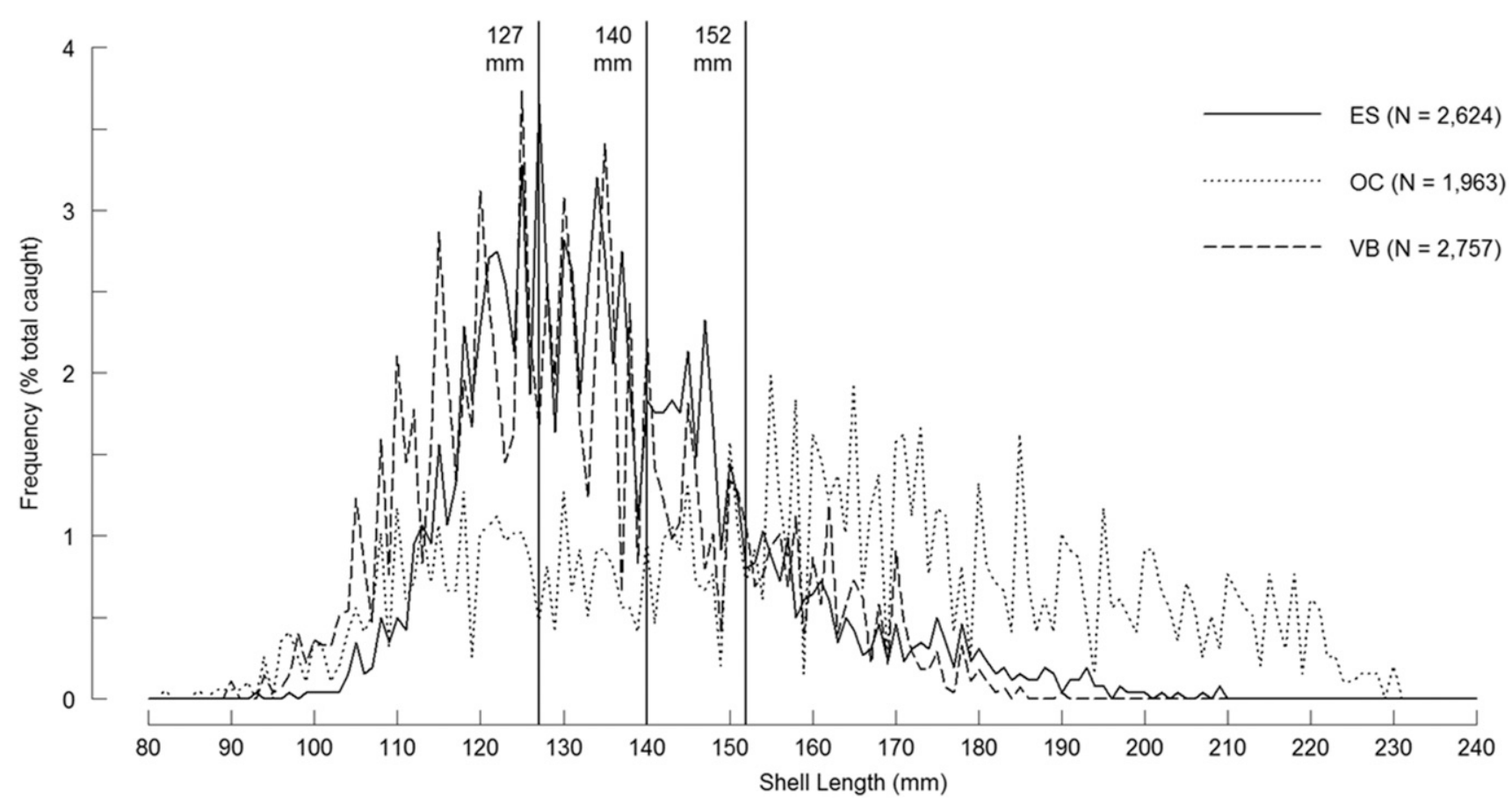

Figure 16. Length frequency distribution (\% of total caught) by sample area with minimum landings sizes (vertical lines) for the regions.

various size classes $(72.4 \mu \mathrm{m}, n=87)$ from all three study areas, the "settlement ring," or "hatching ring" can be considered to reference the period of time in which $B$. canaliculatus juveniles acclimate to benthic life shortly after hatching (observed between day 7 and 14 in this study) and at which enumeration of subsequent signature "rings" for aging commences. Similar environmental conditions between studied resource areas at the time of hatching are suggested because no geographical variation in settlement ring size at formation was observed.
The lack of small, juvenile whelk collected in this study was largely the result of sampling gear selectivity, where commercial traps are designed to allow for the escapement of small whelk. Because the incidental capture of small whelk less than $90 \mathrm{~mm}$ is rare in the fishery (only four whelk less than $90 \mathrm{~mm}$ out of 8,137 caught in traps during this study through various seasons, $82-89 \mathrm{~mm}$ ), the possibility exists that juvenile Busycotypus canalicuatus do not share the same habitats as adults. Furthermore, these juveniles may also inhabit areas different from that of
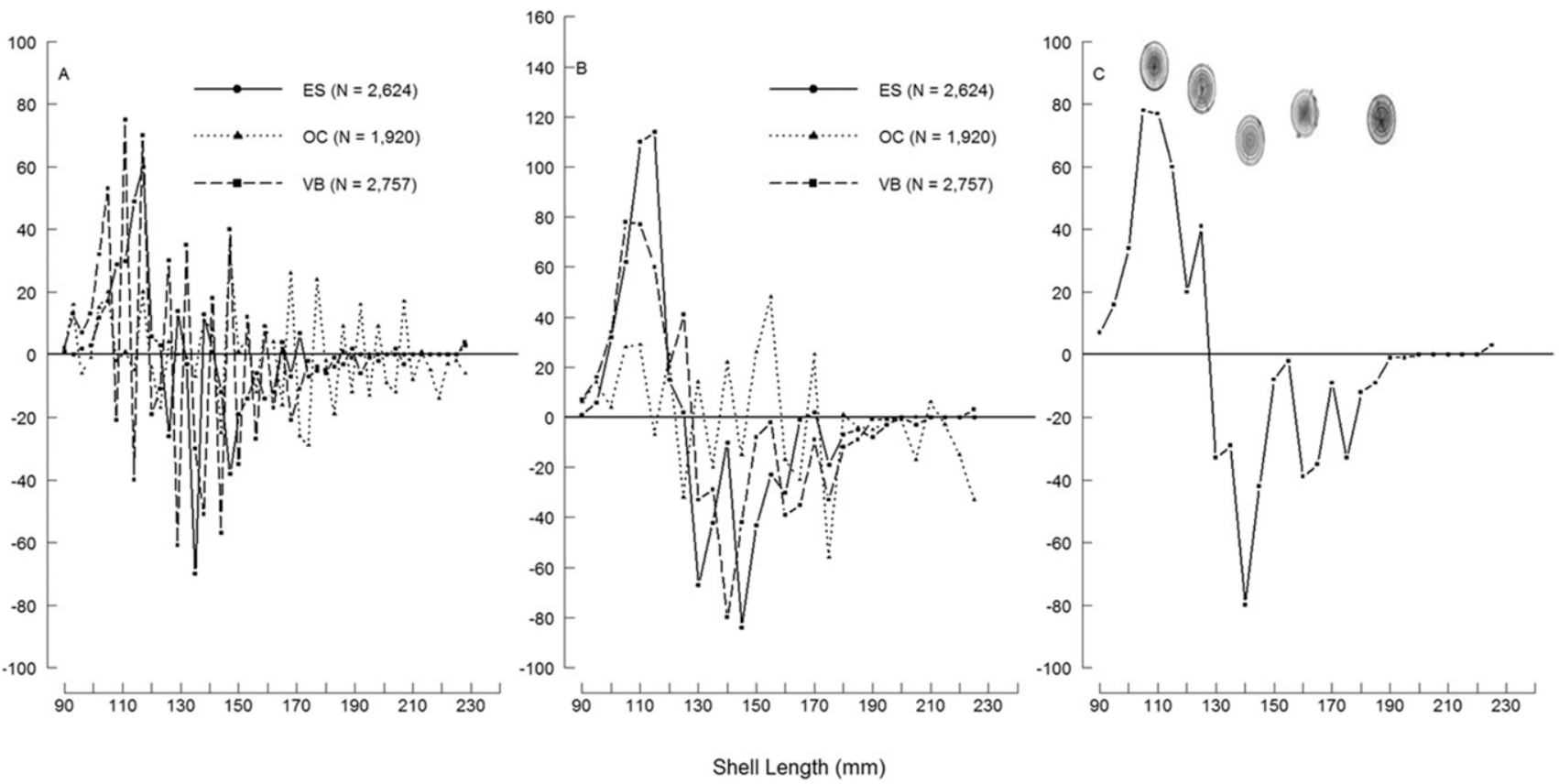

Figure 17. Length frequency distributions of Busycotypus canalicutas by area with shell length binned by $3 \mathrm{~mm}$ (A) and $5 \mathrm{~mm}$ (B). VB $5 \mathrm{~mm}$ binned length frequency distribution with statoliths (estimated ages 4-8 y, left to right) corresponding with shell length ranges spanning distribution peaks (C). 
hatching because they have been rarely observed in the same habitats in which their egg strings have been found (Kraeuter et al. 1989, Castagna \& Kraeuter 1994, Power et al. 2002).

In this study, Busycotypus canalicuatus are observed to mature at different sizes under different management MLS. Male B. canalicuatus growth rate was greater than females in all three resource areas, with males reaching sexual maturity at a smaller size and younger age. Males maturing before females are consistent with most dioecious prosobranchs (Runham 1993), where females are reported to invest more energy in reproduction which delays maturation (Kideys et al. 1993, Brokordt et al. 2003). Spatial variation in size reached at sexual maturity has been reported for Buccinum undatum (Martel et al. 1986a, Kideys et al. 1993, Kenchington \& Glass 1998), Strombus gigas (Avila-Poveda \& Baqueiro-Cárdenas 2006), and Busycon caricas (Power et al. 2009). In this study, size at sexual maturity between areas was observed to differ, but not consistently between the sexes. Males from VB and ES reached sexual maturity at smaller sizes than males from OC. This relationship may be expected because males from ES and VB grow considerably faster (higher $k$ values) than OC males, however, observed female growth rates $(k)$ and size at maturity suggest that VB females reached sexual maturity earlier than OC and ES, even though growth rates for VB and ES females are similar.

The rate of maturation may further be associated with the discarding of sublegal whelk during commercial fishing. In this study, sublegal whelks retained in traps, and therefore percent discard whelks, was much higher in VB $(69 \%)$ than OC $(43 \%)$ even though VB is regulated under a smaller MLS. This situation is consistent with reports from Duncan et al. (1989) and Valentinsson et al. (1999) that sexual maturation is reached at a smaller size in Buccinum undatum populations in which large whelk are heavily exploited. Investigation into alternative trap designs which allow for greater escapement of sublegal whelk may be warranted. Within the Virginia whelk fishery, the size composition of landings has changed since the fishery's development, resulting in fewer large whelk meats (size grades) in the market. A smaller size composition reduces the unit value of the output from the fishery. Although shellstock prices are currently at record levels, they are a function of size composition and would be higher with a larger size composition. From a yield perspective, increasing the MLS from 139.7 to $152.4 \mathrm{~mm} \mathrm{SL} \mathrm{(5.5-}$ 6 in) could result in a 37\% increase in meat yield; reestablish market diversity and increase whelk value. This study did not evaluate the size composition of the commercial catch to determine the corresponding loss of landings associated with a change in MLS although, at least in the short term, there would be a loss of yield as a result of increasing the MLS.

Penis length was used to calculate a standardized index (PI) which is used as an indicator of sexual maturity in the commercially exploited Buccinum undatum (Santarelli-Chaurand 1985, Martel et al. 1986b, Lanteigne \& Davidson 1992, Ilano et al. 2003), with an index more than 0.5 indicating maturity. This method of measuring penis length is not well defined in literature and reports do not state if the penis is measured at rest or somewhere in between rest and fully extended when measured. In one example, the penis was removed from body before measurement (Power et al. 2009). The only published study to date measuring penis length of Busycotypus canaliculatus as an indicator of maturity (Peemoeller \& Stevens 2013) did not report an index or describe how measurements were recorded for this species.
Within sampling of male $B$. canaliculatus for the current study, the attached penis was consistently observed only at rest, and as in other whelk species, folded once along its length with the fold occurring near the base of the penis. Measuring the distil length from the fold provided a consistent, more accurate, and easily performed method of sampling. An estimate of 50\% maturity using this method of penis measurement ranged from 18 to $22 \mathrm{~mm}$ SL between areas sampled with a PI of more than 0.15 .

In this study, 28 males were observed with proportionally small penises. Although penis atrophy in gastropods has been associated with senility (Gendron 1992), penis atrophy in this study was observed in both mature and immature male whelk (101-176 mm SL, average $133.6 \mathrm{~mm}$ ). In all cases involving small penises, whelks were infected with digenetic trematodes, macroscopically observed as an orange colored mass of cells on the ventral side of digestive cecum (opposite and anterior of the gonad). Observed symptoms of infection by this parasite were penis atrophy and nonfunctional (vestigial) gonads and VD. Trematode infection in whelk has been reported to cause reduced penis size and gonadal function (Køie 1969, Tétreault et al. 2000, Rato et al. 2009). At 50\% mature, male penis length ranges from 118 to $122 \mathrm{~mm}$ in normal, noninfected whelk. Average penis length of parasitized males at SL more than $50 \%$ mature $(n=20)$ was $8.0 \mathrm{~mm}$. Infection by this parasite was also found in immature and mature females (113-185 mm SL, ave $145.6 \mathrm{~mm}$ ), which resulted in less developed CG in infected whelk. Histologically, the masses contain sporocysts with developing cercaria, suggesting that Busycotypus canalicualtus serves as an intermediate host for this parasite. In total, 41 of $1,604(2.5 \%)$ B. canaliculatus observed in this study were infected with this parasite (13 female, 28 male). Infected whelks were found in all three areas during each sampling period (fall, spring) and were not included in age, growth, or reproductive maturity evaluation in this study. Although observed at relatively low degree of prevalence, reduced reproductive potential resulting from parasitic involvement should be of concern within these populations.

Within the Busycotypus canaliculatus fishery, breakage of the siphonal canal prevents accurate SL measurement giving rise to management interest in SW measurement for regulatory MLS. Although damage to the siphonal canal has been reported to be a product of feeding strategies in some whelk (Magalhaes 1948, Carriker 1951, Kraeuter et al. 1989), it is routinely observed as a result of whelk-to-whelk physical contact during trap haul-back and on-board handling/culling practices. An accurate and efficient means to measure channeled whelk SW need to be clearly defined because maximum nominal linear shell diameter cannot accurately be measured by traditional low-profile cull rings because of the conical-irregular shape of $B$. canaliculatus whelk. Whelk with a given SW diameter can easily be passed through a cull ring of same diameter by changing the angle of whelk orientation to the ring as whelk is passed through the ring.

Under current MLS for each study area, whelk harvested from VB are recruited into the fishery at a much younger age and smaller size than those from OC (Table 7). Size at first maturity in the Buccinum undatum fishery is also observed to differ between separated resource areas (Hancock 1967, Martel et al. 1986a, Kideys et al. 1993). The probability of Busycotypus canaliculatus females reaching current MLS before sexual maturity is quite low within all resource areas (Table 7).

This work has shown that regional variations of growth and maturity exist in Busycotypus canaliculatus within the Mid-Atlantic 
TABLE 7.

Estimated age at which whelk reach minimum landing size (MLS) as calculated from von Bertalannfy growth parameters.

\begin{tabular}{llccc}
\hline \hline $\begin{array}{c}\text { Resource } \\
\text { area }\end{array}$ & Sex & $\begin{array}{c}\text { MLS } \\
(\mathbf{m m})\end{array}$ & $\begin{array}{c}\text { Calculated } \\
\text { age } \boldsymbol{a} \text { MLS }\end{array}$ & $\begin{array}{c}\text { Probability of } \\
\text { maturity at MLS }\end{array}$ \\
\hline Ocean City & Female & 152.0 & 6.74 & 0.157 \\
& Male & 152.0 & 7.12 & 0.990 \\
Eastern Shore & Female & 139.7 & 5.85 & 0.010 \\
& Male & 139.7 & 6.32 & 0.985 \\
Virginia Beach & Female & 139.7 & 5.00 & 0.086 \\
& Male & 139.7 & 5.60 & 0.990 \\
\hline
\end{tabular}

The probability of a whelk having achieved sexually mature at a given shell height was estimated from the generated maturity ogives.

region of the US. Much of the observed differences in the current study are driven by the results from OC. Growth estimates from this area suggest larger asymptotic sizes and slower growth rates relative to the other resource areas. This observation holds in comparisons to Peemoeller and Stevens (2013) who estimated growth parameters for whelk from Buzzards Bay, MA, that were similar to results from ES and VB and divergent from OC. Maturity results from Massachusetts also suggest differences in age at maturity with animals from that region maturing at an older age for both females and males at $8.6 \mathrm{y}$ and 6.9, respectively (Peemoeller \& Stevens 2013). Size at maturity was similar between the studies, suggesting that some of the observed differences in age may be a function of differing whelk aging techniques.

Other aspects of Busycotypus canaliculatus life history require consideration for conservation management, mainly their sedentary existence, long life span, and significant sexual dimorphism in age at maturity. Being sedentary benthic animals in which free crawling juveniles emerge from an egg capsule directly to the benthos (lack of planktonic larval stage), limited dispersal occurs, creating localized stocks which could be subject to overexploitation. Males maturing at sizes below MLS are allowed to reproduce before legal harvest; however, successful recruitment to a fishery is dependent on female reproductive capacity, and females in the study area reach maturity at a size greater than current MLS.

In fisheries management, the intent of most MLS is to identify a harvestable size which allows for juveniles to survive and spawn at least once. Results indicate that current MLS's are inappropriate for sustainable management of the Busycotypus canaliculatus resource. Size at maturity as estimated here indicates that immature female whelks are removed by the fishery under current MLS regulations, potentially impacting recruitment success and ultimately subjecting the whelk population to overexploitation. Given the life history information generated for B. canaliculatus in both the Mid-Atlantic as well as New England (Peemoeller \& Stevens 2013), fishery managers now have a basis to re-evaluate fishery management strategies for this species to ensure the sustainability and productivity of the fishery and the resource.

\section{ACKNOWLEDGMENTS}

The authors thanks commercial conch fishermen Jimmy Hahn, Troy Hainley, and Don Miles for collaborating for this work, Virginia Marine Resource Commission and Maryland DNR for scientific collection permitting, Richard Robins for project management assistance and editorial review, John Hoenig from VIMS for statistical and modeling assistance and evaluations, Sayer Fisher for assistance with whelk processing and aging, and Sally Roman for article preparation assistance. Funding support was provided through the Virginia Fishery Resource Grant Program administered by the VIMS Marine Advisory Program in partnership with the Virginia Sea Grant Marine Extension Program.

\section{LITERATURE CITED}

Abbott, R. T. 1974. American seashells, $2^{\text {nd }}$ edition. New York, NY: van Nostrand Reinhold. $663 \mathrm{pp}$.

Anderson, B. A., A. G. Eversole \& W. D. Anderson. 1989. Variations in shell and radula morphologies of knobbed whelks. J. Shellfish Res. 8:213-218.

Avila-Poveda, O. H. \& E. R. Baqueiro-Cárdenas. 2006. Size at sexual maturity in the queen conch Strombus gigas from Colombia. Bol. Investig. Mar. Costeras 35:223-233.

Barroso, C. M., M. Nunes, C. A. Richardson \& M. H. Moreira. 2005. The gastropod statolith: a tool for determining the age of Nassarius reticulatus. Mar. Biol. 146:1139-1144.

Bhattacharya, C. G. 1967. A simple method of resolution of a distribution into Gaussian components. Biometrics 23:115-135.

Brokordt, K. B., H. E. Guderley, M. Guay, C. F. Gaymer \& L. H. Himmelman. 2003. Sex differences in reproductive investment: maternal care reduces escapes capacity in the whelk Buccinum undatum. Mar. Ecol. Prog. Ser. 291:161-180.

Bruce, D. 2006. The whelk dredge fishery of Delaware. J. Shellfish Res. 25:1-13.

Carriker, M. R. 1951. Observations on the penetration of tightly closing bivalves by Busycon and other predators. Ecology 32:73-83.

Castagna, M. \& J. N. Kraeuter. 1994. Age, growth rate, sexual dimorphism, and fecundity of knobbed whelk Busycon carica (Gmelin, 1791) in a western Mid-Atlantic lagoon system, Virginia. J. Shellfish Res. 13:581-585.
Chatzinikolaou, E. \& C. A. Richardson. 2007. Evaluating growth and age of netted whelk Nassarius reticulatus (Gastropoda: Nassariidae) using statolith growth rings. Mar. Ecol. Prog. Ser. 342:163-176.

Cledón, M., W. Arntz \& P. E. Penchaszadeh. 2005. Gonadal cycle in an Adelomelon brasiliana (Neogastropoda: Volutidae) population of Buenos Aires province, Argentina. Mar. Bio. 147:439-445.

Davis, J. P. \& R. T. Sisson. 1988. Aspects of the biology relating to the fisheries management of New England populations of the whelks, Busycotypus canaliculatus and Busycon carica. J. Shellfish Res. 7:453-460.

Dicosimo, J. 1988. Commercial fisheries analysis of Busycon whelks in Virginia. J. Shellfish Res. 7:155.

Duncan, A., C. Gilling, G. Hughes, S. J. Hawkins \& R. D. M. Nash. 1989. The viability of establishing a whelk fishery in Manx waters. A report submitted to the Isle of Man Government, Department of Agriculture, Fisheries and Forestry, by the University of Liverpool. $73 \mathrm{pp}$.

Edwards, A. L. \& M. G. Harasewych. 1988. Biology of the recent species of the subfamily Busyconinae. J. Shellfish Res. 7:467-472.

Efron, B. \& R. J. Tibshirani. 1993. An introduction to the bootstrap. New York, NY: Chapman \& Hall/CRC Monographs on Statistics \& Applied Probability.

Eversole, A. G., W. D. Anderson \& J. Isely. 2008. Age and growth of knobbed whelk Busycon carica (Gmelin, 1791) in South Carolina subtidal waters. J. Shellfish Res. 27:423-426. 
Fahy, E., E. Masterson, D. Swords \& N. Forrest. 2000. A second assessment of the whelk fishery Buccinum undatum in the southwest Irish Sea with particular reference to its history of management by size limit. In: Irish fisheries investigations, vol. 6. Dublin, Republic of Ireland: Fisheries Science Services, Marine Institute. pp. 1-67.

Gendron, L. 1992. Determination of the size at sexual maturity of the waved whelk Buccinum undatum Linnaeus, 1758, in the Gulf of St. Lawrence, as a basis for the establishment of a minimum catchable size. J. Shellfish Res. 11: 1-7.

Hancock, D. A. 1967. Whelks, Laboratory leaflet no. 15. Lowestoft, United Kingdom: Ministry of Agriculture, Fisheries and Food. pp. 1-14.

Harding, J. M. 2011. Observations on the early life history and growth rates of juvenile channel whelks Busycotypus canaliculatus (Linnaeus, 1758). J. Shellfish Res. 30:901-903.

Heude-Berthelin, C., L. Hégron-Macé, V. Legrand, A. Jouaux, B. Adeline, M. Mathieu \& K. Kellner. 2011. Growth and reproduction of the common whelk Buccinum undatum in west Cotentin (Channel), France. Aquat. Living Resour. 24:317-327.

Ilano, A. S., K. Fujinaga \& S. Nakao. 2003. Reproductive cycle and size at sexual maturity of the commercial whelk Buccinum isaotakii in Funka Bay, Hokkaido, Japan. J. Mar. Biol. Assoc. U.K. 83:1287-1294.

Kenchington, E. \& A. Glass. 1998. Local adaptation and sexual dimorphism in the waved whelk (Buccinum undatum) in Atlantic Nova Scotia with applications to fisheries management. Can. Tech. Rep. Fish. Aquat. Sci. 2237:43.

Kideys, A. E., R. D. M. Nash \& R. G. Hartnoll. 1993. Reproductive cycle and energetic cost of reproduction of the neogastropod Buccinum undatum in the Irish Sea. J. Mar. Biol. Assoc. U.K. 73:391-403.

Køie, M. 1969. On the endoparasites of Buccinum undatum L., with special reference to the trematodes. Ophelia 6:251-279.

Kraeuter, J. N., M. Castagna \& R. Bisker. 1989. Growth rate estimates for Busycon carica (Gmelin, 1791) in Virginia. J. Shellfish Res. 8: 219-225.

Lanteigne, M. \& L. A. Davidson. 1992. Overview of the yield per trap and shell height at sexual maturity for waved whelk, Buccinum undatum, caught on the eastern coast of New Brunswick - 1992. Can. Tech. Rep. Fish. Aquat. Sci. 1896:23.

Magalhaes, H. 1948. An ecological study of snails of the genus Busycon at Beaufort, North Carolina. Ecol. Monogr. 18:377-409.

Manion, M., A. West \& R. Unsworth. 2000. Economic assessment of the Atlantic coast horseshoe crab fishery. Prepared by Industrial Economics, Incorporated, Cambridge, MA for the Division of Economics, U.S. Fish and Wildlife Services, Arlington, VA, April 7, 2000.

Martel, A., D. H. Larrivée, K. R. Klein \& J. H. Himmelman. 1986a. Reproductive cycle and seasonal activity of the neogastropod Buccinum undatum. Mar. Biol. 92:211-221.

Martel, A., D. H. Larrivee \& J. H. Himmelman. 1986b. Behaviour and timing of copulation and egg-laying in the neogastropod Buccinum undatum L. J. Exp. Mar. Biol. Ecol. 96:27-42.

McQuinn, I. H., L. Gendron \& J. H. Himmelman. 1988. Area of attraction and effective area fished by a whelk (Buccinum undatum) trap under variable conditions. Can. J. Fish. Aquat. Sci. 45:2054 2060.
Peemoeller, B. J. \& B. G. Stevens. 2013. Age, size, and sexual maturity of channeled whelk (Busycotypus canaliculatus) in Buzzards Bay, MA. Fish. Bull. 111:265-278.

Power, A. J., E. Covington, T. Recicar, R. L. Walker \& N. Eller. 2002. Observations on the egg capsules and hatchlings of the knobbed whelk Busycon carica (Gmelin, 1791) in coastal Georgia. J. Shellfish Res. 21:769-775.

Power, A. J. \& B. F. Keegan. 2001. Seasonal patterns in the reproductive activity of the red whelk, Neptunea antiqua (Mollusca: Prosobranchia) in the Irish Sea. J. Mar. Biol. Assoc. U.K. 81:243-250.

Power, A. J., C. Sellers \& R. L. Walker. 2009. Growth and sexual maturity of the knobbed whelk, Busycon carica (Gmelin, 1791) from a commercially harvested population in coastal Georgia, vol. 4. Occasional Papers of the University of Georgia Marine Extension Service, Athens, Greece. 24 pp.

Rato, M., F. Russel-Pinto \& C. Barroso. 2009. Assessment of digenean parasitism in Nassarius reticulatus (L.) along the Portuguese coast: evaluation of possible impacts on reproduction and imposex expression. J. Parasitol. 95:327-336.

Richardson, C. A., C. Saurel, C. M. Barroso \& J. Thain. 2005. Evaluation of the age of the red whelk Neptunea antiqua using statoliths, opercula and element ratios in the shell. J. Exp. Mar. Biol. Ecol. 325:55-64.

Runham, D. W. 1993. Reproductive biology of invertebrates. In: Adiyodi, K. G. \& R. G. Adiyodi, editors. Asexual propagation and reproductive strategies, vol. VI, part A. New York, NY: John Wiley \& Sons. pp. 311-384.

Santarelli-Chaurand, L. 1985. Les pecheries de buccin (Buccinum undatum L.: Gastropoda) du Golfe Normand-Breton. Element de gestion de la ressource. These de Doctorat, Universite d'AixMarseille II, France. 194 pp.

Shalack, J. 2007. Movement and behavior of whelks (Family Melongenidae) in Georgia coastal waters. Master Thesis, University of Georgia, School of Marine Programs, Athens.

Shelmerdine, R. L., L. Adamson, C. H. Laurenson \& B. Leslie. 2007. Size variation of the common whelk, Buccinum undatum, over large and small spatial scales: potential implications for micro-management within the fishery. Fish. Res. 86:201-206.

Tétreault, F., J. H. Himmelman \& L. Measures. 2000. Impact of a castrating trematode, Neophasis sp., on the common whelk, Buccinum undatum, in the northern Gulf of St. Lawrence. Biol. Bull. 198:261-271.

Thomas, M. L. H. \& J. H. Himmelman. 1988. Influence of predation on shell morphology of Buccinum undatum L. on Atlantic coast of Canada. J. Exp. Mar. Biol. Ecol. 115:221-236.

Valentinsson, D., F. Sjödin, P. R. Jonsson, P. Nilsson \& C. Wheatley. 1999. Appraisal of the potential for a future fishery on whelks (Buccinum undatum) in Swedish waters: CPUE and biological aspects. Fish. Res. 42:215-227.

Walker, R. L., A. J. Power, M. Sweeney-Reeves, E. Covington, M. Mitchell \& T. Recicar. 2008. Growth, migration, population structure and sex ratio of four whelk species (Family Melongenidae) within Wassaw Sound, Georgia. Marine Extension Service. University of Georgia. 1:46. 